\title{
ANTASARI's Developing Blended Learning Model Based on Ecopedagogy Study to Improve Ecological Awareness, Soft and Social Skills on Elementary Education
}

\author{
Ahmad Suriansyah $^{1 *}$ Akhmad Riandy Agusta ${ }^{2}$ Ananda Setiawan ${ }^{3}$ \\ ${ }^{1}$ Master of Education Management, Postgraduate, Lambung Mangkurat University, Banjarmasin, Indonesia \\ ${ }^{2}$ Elementary School Teacher Education, FKIP, Lambung Mangkurat University, Banjarmasin Indonesia \\ ${ }^{3}$ Department of Economics Education, FKIP, Lambung Mangkurat University, Banjarmasin Indonesia \\ ${ }^{*}$ Corresponding author. E-mail:a.suriansyah@ulm.ac.id
}

\begin{abstract}
This research will show about (1) the characteristics and implementation of the ANTASARI blended learning model; (2) The appropriateness of implementation blended learning model ANTASARI; (3) the effectiveness of the ANTASARI implementation blended learning model to improve soft and social skills pass for the COVID-19 pandemic. The method of this research uses Research and Development (R\&D) with the Four-D model (definition, design, development, and dissemination). The sample of this research is 45 person elementary school students on Banjarmasin. Collecting data use observation, documentation, interview, test, and questionnaire. Observation is used to know the effectiveness of implementation of the blended learning model, the improvement of critical thinking, problem-solving and independence, collaboration, negotiationand communication. Documentation is used to collect every document along with the implementation of this model. The interview is used to know the effectiveness of this model from the teacher and student side. The test is used to know the improvement of critical thinking and problem-solving skills. The last, questionnaire is used to know the effectiveness of the implementation of a blended learning model ANTASARI to improve soft and social skills. Data analysis uses the Interactive Model from Miles and Huberman. The indicator of this research improvement of soft skills included: critical thinking, problemsolving and independence and social skills included: collaboration, negotiation and communication. The result shows that (1) the characteristic and implementation of the blended learning model ANTASARI consist of Auditory, Negotiation, Team, Analysis, Somatic, Administer Information, Role Play and Interaction on Games; (2) ANTASARI's blended learning model is appropriate to be used according to the results of the validation from 3 experts with validation percentage of learning steps $91 \%$, skills improvement $84.56 \%$ and teaching materials $86 \%$. (3) ANTASARI's blended learning model is effective to be used in learning based on the results of evaluations using instruments of soft and social skills. The improvement after implementation blended learning model, the students who are getting high criteria on ecological awareness from 6,7\% increase to $75,6 \%$, critical thinking from $8,8 \%$ increase to $84,2 \%$, problem-solving from $8,2 \%$ increase to $81,3 \%$, independence from $6,5 \%$ increase to $80,6 \%$, collaboration from $7,2 \%$ increase to $81,4 \%$, negotiation from $9,3 \%$ increase to $77,6 \%$, and communication from $15,6 \%$ increase to $77.2 \%$. The conclusion is blended learning model ANTASARI can improve students' soft and social skills in elementary education.

Keywords: Blended Learning, Antasari, Social Skills, Elementary Education
\end{abstract}

\section{INTRODUCTION}

Quality learning in the era of the industrial revolution 4.0 is shown by the products of students who have the skills that society needs today. To realize a generation of students who have these skills, we need learning strategies that lead to the development of the expected skills. This is because the learning strategy can direct how students learn by incorporating elements of practicing the expected skills.
This is what makes learning strategies always develop from time to time by following the needs of society in the future[1,2,3] The needs of society today are not only focused on higher-order thinking skills, but are directed towards having social skills [4]. Based on community needs, teachers are expected to have the ability to present learning that leads to the development of social skills[1,2,3,5,4]. 
The priority skills to be developed in the current learning process are environmental care, interpersonal intelligence, critical thinking skills, creative thinking skills, problem solving, independence, group work and communication $[6,7,8,9,1,10,11]$.

Skills development that is demanded by society in the future must be carried out in various conditions and situations. This view is very important in the midst of conditions in this country which must carry out learning from home to prevent the spread of the COVID-19 virus. Learning from home is not a big obstacle to prioritizing the development of higher order thinking skills in elementary school age children. This is based on the important role of higher-order thinking skills to give birth to a productive generation and ensure the progress of this country. A skill that should be developed since elementary school age is critical thinking. If students have these skills, they are able to think deeply and structurally and dare to present the truth and evaluate various things in a multiperspective way $[12,13,14,1]$.

A skill that is no less important for future generations to have is creativity. A creative person will be able to innovate through the development of broad ideas and put forward new opinions and findings to solve problems in social life, have a high curiosity to seek the truth of an opinion, and even make students able to be open and responsive to different perspectives. . Creative thinking is characterized by fluency, flexibility, originality $[14,2,5,4,15]$.

Skills that support critical and creative thinking are problem solving. Suriansyah, Aslamiah, Sulaiman \& Noorhafizah (2014) suggest that problem solving activities allow students to have in-depth analysis skills of a problem that arises around their lives, then solve it through rational solutions and logically acceptable thinking. With this skill, a person will have an adequate understanding of seeing reality and have a desire to solve problems straightforwardly and precisely. Problem solving abilities are a series of procedures or strategies that allow a person to increase independence in thinking $[6,16,17,18]$.

The development of higher-order thinking skills that is focused on critical thinking, creative thinking and problem solving skills we know familiarly with direct interaction by exploring problems openly. This is because the data search is assumed to have a high level of validity if it is obtained through direct interaction with the object of study. However, during the Covid-19 virus pandemic, it was impossible to obtain data through direct interaction with the object of research. In the midst of the high spread of viruses that can endanger human lives, every level is competing to develop strategies that are able to train students' thinking skills even if it is done without face-toface interaction in the classroom.

Blended Learning is learning that combines direct interaction to transfer knowledge combined with media in the form of interactive CDs and electronic books that are accessed via the internet network [19]. Efforts to use blended learning for the development of learning communities in the network are implemented by various levels of education, which are not only distance education providers (PJJ), but have penetrated the educational community that implements independent learning with various media. They integrate various components of online learning with conventional classrooms[19,19,20].

Researchers suggest that learning is said to be Blended Learning when it combines at least two learning methods aimed at achieving learning demands. Thorne [21] reveals a condition that can be observed in traditional classrooms that require teachers and students to meet face to face in the transfer of knowledge, but by utilizing an internet network, learning can be done anywhere and anytime not bound by time and distance.

A condition that we often encounter is blended learning based on virtual learning that brings together students and teachers. They can interact even though they are in different places, allowing them to be in tough situations such as during the Covid-19 virus pandemic. Sneezing [20]supports this statement through the results of his research which suggests that blended learning is carried out by combining several different methods, both in the form of technology, internet, activities and various situations in order to carry out optimal learning for certain students. Blended learning implies conventional learning combined with electronic facilities and internet networks. This is a learning alternative that can be used to overcome the limitations of direct interaction such as time, distance, and various other situations that prevent conventional learning from running.

Blended learning puts students forward as an important factor who will be given a variety of independent knowledge and give rise to analytical, critical and creative attitudes. Thus, various educational institutions today must be able to create strategies in the form of blended learning that are designed according to student characteristics and skills that will be developed according to community demands [22,23].

Based on this background, the researcher seeks to analyze the results of the development of a blended learning model that contains high-level thinking skills within the boundaries of critical thinking, creative thinking and problem solving amid social restrictions and interactions between teachers and elementary school students. The learning model developed is called the ANTASARI blended learning model (Kinesthetic, Audiovisual, Science, Technology, Performance, Resolution and Identification).

The formulation of the problem in this research is How is the application of the ANTASARI blended learning model (Kinesthetic, Audiovisual, Science, Technology, Performance, Resolution and Identification)? Is the ANTASARI blended learning model (Kinesthetic, Audiovisual, Science, Technology, Performance, Resolution and Identification) effective in improving the higher order thinking skills of elementary school students?

\section{METHOD}

Based on the problems to be resolved, the researcher uses a research method in the form of research and development (R \& D) or what is known as research and 
development in the field of education with the model proposed by Borg \& Gall. This method is used to create innovation and validate a product from the world of education in the form of strategies, methods, goals, curriculum, evaluation tools, educational software or hardware or the process of using them[24]. This research will produce innovative products that are different from other products, both modified and new products to support work in the world of education and learning. This product allows the teaching and learning process to be optimal to achieve the expected goals[25].

The steps in the research research and development research method (R \& D) Thiagarajan, Semmel, Semmel (1974) are known as the 4D method (Define, Design, Develop, and Disseminate). The define stage is the stage for determining and defining the terms of learning. The define stage includes five main steps, namely front-end analysis, student analysis (learner analysis), teacher analysis, skill development analysis and formulation of learning objectives (specifying instructional objectives). ). The design stage aims to design a learning model. Four steps must be taken at this stage, namely: (1) preparation of skills to be developed, (2) preparation of learning steps, (3) examining the meaning and purpose of each learning step. The next stage is develop, this stage will produce a product development which is carried out in two steps, namely: (1) expert appraisal followed by revision, (2) developmental testing. The last process is disseminate, this stage is the final stage of development. The dissemination stage is carried out to promote the development product to be accepted by users, whether individuals, a group, or a system. According to Thiagarajan et al [26], "the terminal stages of final packaging, diffusion, and adoption are most important although most frequently overlooked."

The define stage was carried out to determine the blended learning model used in several schools in Banjarmasin during the Covid-19 pandemic with the following stages: front-end analysis explores information on the blended learning model used in several elementary schools in Banjarmasin City, the skills developed in the blended learning model that has been used and the development needs of the blended learning model to meet the needs of today's society. Student analysis (learner analysis) explores information on student activities in the learning process and learning activities expected by students. Teacher analysis (teacher analysis), the role of teachers in controlling learning, developing students' thinking and social skills, teacher difficulties in developing student skills, obstacles when using blended learning. Analysis of skills developed (skill development analysis), skills developed in the blended learning model that have been used, evaluation procedures in the learning process whether they contain ecological awareness skills, soft skills, and whether the blended learning model used has developed students' social skills. The formulation of learning objectives (specifying instructional objectives), determining learning objectives that are oriented towards developing ecological awareness skills, soft and social skills, and determining how to develop each item of students' thinking and social skills. and whether the blended learning model used has developed students' social skills. The formulation of learning objectives (specifying instructional objectives), determining learning objectives that are oriented towards developing ecological awareness skills, soft and social skills, and determining how to develop each item of students' thinking and social skills. and whether the blended learning model used has developed students' social skills. The formulation of learning objectives (specifying instructional objectives), determining learning objectives that are oriented towards developing ecological awareness skills, soft and social skills, and determining how to develop each item of students' thinking and social skills.

The design stage starts from the preparation of the skills to be developed. This skill arrangement is carried out based on the analysis that has been done previously. After knowing the priority skills to be developed in elementary schools, the researchers compiled the ANTASARI blended learning model steps. Each step of the model is analyzed in depth for the substances and skills that can be developed after carrying out these steps.

The next stage is develop, this stage will produce product development which is carried out in two steps, namely expert appraisal followed by revision and developmental testing. Expert assessment is carried out by three people who are selected from three points of view, namely experts on learning steps, experts on skills developed and experts in media and technology. Furthermore, a wider model trial was conducted to determine the effectiveness of the model through repeated actions based on the opinion of Hopkins[27]which includes activities (1) planning strategies for implementing the blended learning model, (2) implementing blended learning, (3) reflection learning outcomes and processes, and (4) observation and improvement of the learning process. The trial process was carried out in four learning meetings, for grade 5 students at SDN Pasar Lama 1 Banjarmasin and SDN Sungai Miai 7 Banjarmasin. The first stage was carried out on grade 5 students at SDN Pasar Lama Banjarmasin with a total of 30 students. the second stage was carried out on grade 5 students of SDN Sungai Miai 7 Banjarmasin with a total of 30 students. So it is possible that there is more complete variation and accuracy of data to improve ANTASARI's blended learning model so that it is considered effective in developing students' high-level and social thinking skills. Product feasibility trials are conducted to determine the feasibility level. Based on the deficiencies in the trial results, the researchers made revisions to the parts that were still inadequate, so as to produce a product that was suitable for use. Product trial designs are carried out to obtain data that will be used to determine product deficiencies that are developed as a basis for revising products[25]. In addition, the purpose of the trial was to determine the feasibility and effectiveness of ANTASARI's blended learning.

Collecting data in this study using observation, documentation, interview, test and questionnaire techniques [25]. Observation is used to determine the effectiveness of using the ANTASARI blended learning model, developing ecological awareness skills in the form 
of exploring environmental issues, packaging action strategies to overcome environmental issues, skills to act on environmental issues, responding skills and a good personality attitude. Furthermore, soft skills in the form of critical thinking skills in solving problems and independence. As well as social skills in the form of cooperation, negotiation and communication. Observation of the effectiveness of learning using the ANTASARI blended learning model using observation sheets of teacher activities and student activities in each learning step that has been compiled. Researchers will assess how the quality of learning using the new learning model is compared to previous conditions. Observations will also be used to determine the improvement of each skill item based on the grid collected from the opinions of experts. Each student activity will be observed whether they have critical thinking skills, problem solving, independence, cooperation, negotiation and communication.

Documentation is used to collect documents during the implementation of the ANTASARI blended learning model. Documents collected are notes during the learning process, input and improvements from reviewers, photos and videos during the learning process, student work and products produced during the learning process using the ANTASARI blended learning model. In addition to documentation, researchers also use interviews to collect information from the teacher when implementing the learning model and students while participating in the learning process. Interviews with teachers explore information about the effectiveness, efficiency and practicality of using learning models. Interviews with students explored information about their interest, practicality and progress in developing their independence, cooperation, negotiation and communication.

The test technique is used to explore students' abilities in critical thinking, creative thinking and problem solving. The test instruments used in the form of essays and multiple choice were prepared based on cognitive verbs related to critical thinking skills, critical thinking and problem solving starting from $\mathrm{C} 4$. The test was carried out before and after using the ANTASARI blended learning model using the same material. Researchers will compare the results obtained in the initial test (pretest) and the final test (posttest) after receiving treatment. The next technique is a questionnaire. This technique is used to extract information from the teacher about the effectiveness of using the learning model compared to the results of interviews. This technique also explores information on students'

The data analysis in this study was carried out qualitatively and quantitatively, regarding the implementation of the learning model. Qualitative analysis is used to describe the results of preliminary research, quantitative analysis related to the implementation and influence of the developed model. Quantitative analysis used statistical analysis[28]. Activities in data analysis include grouping data based on variables and types of respondents, tabulating data based on variables from all respondents, presenting data for each variable studied, performing calculations to answer problem formulations, and performing calculations to test hypotheses that have been proposed.

The data analysis in question is to test the research hypothesis by using the two-party similarity test: the twoparty test, namely the t test. Data obtained from the pretest and posttest data through a questionnaire. The formula for $\mathrm{t}$ is compared with $\mathrm{t} 1-\alpha$ obtained from the $\mathrm{t}$ distribution list with odds $(1-\alpha)$ and $d k=(n 1+n 2-2)$. To test the hypothesis, which is to see whether or not there is a difference in the results of the observation of independent learning before the experiment with the results of the observation of independence after the experiment, the $t$ test is used with a significant level of $\alpha=0.05$.

\section{RESULT}

Research and development was carried out from April to July 2020 during the Covid-19 pandemic, which required all schools in South Kalimantan to carry out learning from home. The results of this study will be presented in three parts consisting of learning conditions during the Covid-19 pandemic at SDN Pasar Lama 1 Banjarmasin, the development of the ANTASARI blended learning model and the effectiveness of the ANTASARI blended learning model to improve the high- level of thinking skills of elementary school students.

\subsection{Learning Conditions during the Covid-19 Pandemic at SDN Pasar Lama 1 Banjarmasin}

At the beginning of March 2020, the Banjarmasin City government announced a large-scale preparatory period for social restrictions after more than 20 Banjarmasin residents tested positive for the Covid-19 Virus. This condition requires all schools in the city of Banjarmasin to be closed and the teaching and learning process to be shifted from face-to-face to online-based learning.

This condition requires teachers at SDN Pasar Lama 1 Banjarmasin to implement learning from home even though with a simple method, namely using the Whatsapp application group. The teacher provides learning in the form of voice and video recordings, then accompanied by assignments that must be done by students. However, the collection of product assignments is done by handing them directly to the teacher at the school. This learning method is boring for students after running for one month. In addition, SDN Pasar Lama 1's mission which prioritizes the development of ecological awareness, thinking skills and social skills is not running optimally.

Seeing this fact, researchers who are colleagues of teachers at SDN Pasar Lama 1 Banjarmasin are looking for effective ways to develop learning that leads to the development of ecological awareness, soft and social skills even though they have to learn from home. 


\subsection{Learning Conditions during the Covid-19 Pandemic at SDN Pasar Lama 1 Banjarmasin}

At the beginning of March 2020, the Banjarmasin City government announced a large-scale preparatory period for social restrictions after more than 20 Banjarmasin residents tested positive for the Covid-19 Virus. This condition requires all schools in the city of Banjarmasin to be closed and the teaching and learning process to be shifted from face-to-face to online-based learning.

This condition requires teachers at SDN Pasar Lama 1 Banjarmasin to implement learning from home even though with a simple method, namely using the Whatsapp application group. The teacher provides learning in the form of voice and video recordings, then accompanied by assignments that must be done by students. However, the collection of product assignments is done by handing them directly to the teacher at the school. This learning method is boring for students after running for one month. In addition, SDN Pasar Lama 1's mission which prioritizes the development of ecological awareness, thinking skills and social skills is not running optimally.

Seeing this fact, researchers who are colleagues of teachers at SDN Pasar Lama 1 Banjarmasin are looking for effective ways to develop learning that leads to the development of ecological awareness, soft and social skills even though they have to learn from home.

\subsection{ANTASARI's Development Blended Learning (Auditory, Negotiation, Team, Analysis, Somatic, Administer Information, Role Play and Interaction on Games)}

\subsubsection{Define}

The development stage begins with the efficiency stage by collecting information to analyze the needs of SDN Pasar Lama 1. Information is collected through five analysis activities. front-end analysis, learner analysis, teacher analysis, skill development analysis, and (specifying instructional objectives.

Based on the front-end analysis conducted by conducting virtual interviews using the Google Meet application with high-grade teachers at SDN Pasar Lama 1, which consisted of 3 class 4 homeroom teachers, 3 class 5 homeroom teachers, 3 class 6 homeroom teachers and the principal. Information was obtained that: (1) teachers find it difficult to interact directly with students to develop critical thinking skills that require teachers to provoke children to ask questions, answer questions orally, provide mutual corrections to friends' answers and provide various answers; (2) learning is very limited to providing material in the form of voice messages and through videos that must be made one day before learning, this will hinder the development of students' abilities to explore problems with teacher directions in depth, providing facts around them which are usually done quickly through direct questioning, distinguishing relevant and less relevant arguments, generating a large number of ideas; (3) learning cannot evaluate the ability of students to argue and express their thoughts, this will hinder the development of skills to think of different ways to solve problems, produce something new from developing existing ideas, develop other people's ideas by providing additional or a stimulus for a simple idea to make it look more attractive, explaining the meaning of a given idea, understanding the problem by describing the problem using one's own language; (4) learning cannot ensure that students explore the environment in ecopedagogy content that is included in learning social knowledge content, as well as various things related to learning topics that are usually directed through seeing directly the object of study in the surrounding environment. This will hinder the development of students' abilities to develop ecological awareness, present problems in detail, have high curiosity by exploring problems through various future-oriented questions, developing problem-solving strategies, finding solutions with various ways of extracting information, solving different problems. from friends, producing alternative solutions to various problems. developing problem-solving strategies, finding solutions with various ways of extracting information, solving different problems. from friends, producing alternative solutions to various problems. developing problem-solving strategies, finding solutions with various ways of extracting information, solving different problems. from friends, producing alternative solutions to various problems.

Based on the learner analysis conducted by conducting virtual interviews using the Google Meet application with high-grade students at SDN Pasar Lama 1, consisting of 60 grade 4 students, 54 grade 5 students, 57 grade 6 students. Based on this analysis, information on various student complaints is obtained, then the information is sorted and converted into the language of the researcher as follows:

a. Learning seems boring, because it is only oriented towards giving assignments

b. Learning is sometimes unclear because they cannot interact with the teacher

c. There is no activity to explore the surrounding environment because it only completes assignments given by the teacher from books and whatsapp

d. Learning is less fun because there are no activities that can generate motivation

e. Learning feels less meaningful because activities are not diverse.

f. There is no problem exploration activity as is usually done in the classroom.

g. Learning does not present group activities and cannot interact with friends.

h. The task is only in the form of answering questions, there is no prospect activity as before.

Furthermore, based on teacher analysis, which was conducted by conducting virtual interviews using the Google Meet application with high-grade teachers at SDN Pasar Lama 1, which consisted of 3 homeroom teachers in grade 4, 3 homeroom teachers from grade 5, 3 homeroom teachers from grade 6 and the principal. Information was obtained that: 
a. Learning that is currently being carried out is only done by giving assignments through WhatsApp groups of students and parents.

b. Learning activities cannot be varied due to the limited ability of teachers to develop online learning activities.

c. Most teachers don't know how to package attractive online learning.

d. The teacher's perception of online learning is learning by sending literature, learning videos and assignments through social media.

e. Teachers cannot supervise students directly while doing assignments.

f. Teachers do not know how to package online learning with the development of students' ecological awareness in ecopedagogy content, especially in social studies content.

g. Teachers do not yet have a maximum way to develop student soft skills such as critical thinking skills, problem solving and curiosity if learning is only assisted by social media.

h. Teachers cannot develop students 'social skills because teachers' perceptions of the online learning process limit interactions between students and interactions between teachers and students.

Based on the information collected from teachers and students of SDN Pasar Lama 1 Banjarmasin, the researcher conducted a skill development analysis and specifying instructional objectives. The analysis results are detailed as follows:

a. The blended learning model that is developed must contain ecological concerns, soft skills and student social skills

b. Ecopedagogy skills that will be developed consist of exploring environmental issues, packaging action strategies to overcome environmental issues, acting skills on environmental issues, attitude skills and good personality attitudes.

c. Soft skills that will be developed in the form of critical thinking skills, problem solving and independence.

d. Social skills that will be developed in the form of cooperation, negotiation and communication. e. Evaluation procedures in the learning process are designed to contain students' ecological awareness skills, soft skills, and social skills.

\subsubsection{Design stage}

The second development stage is design creation. The activity begins with planning, at this stage, the researcher does the following: The planning stage in implementing this model takes several activities, including: (1) identifying learning materials, researchers and teachers reviewing the material to be delivered in accordance with the continuity of previous learning; (2) Designing learning steps using ANTASARI blended learning; (3) Determining the types of network-based learning media, namely interactive learning videos, google meet applications and zoom meetings, ensuring adequate internet networks and determining learning materials. Interactive video media containing material about Humans and the Environment, Environmental Change, Environmental Conservation Efforts that contain problems accompanied by projectbased activities in each lesson. (4) making learning tools such as learning implementation plans, teaching materials containing the theme of our Friends Environment (Theme 8 in the 2013 revised 2018 curriculum) which has been modified according to the needs of blended learning, as well as teacher guides to implement the ANTASARI blended learning model. (5) include ecopedagogy content in learning activities. (6) identify the skills developed in each step of the ANTASARI blended learning model.

Furthermore, researchers developed a preliminary product format (develop a preliminary form of product). Product development begins with determining the substance of the ANTASARI blended learning model. The ANTASARI model is a blended learning model that puts forward virtual or online learning but is accompanied by detailed activities to increase children's ecological awareness, soft skills and social skills.

The development was continued by designing ANTASARI's blended learning steps which were detailed as follows:

Table 1 The steps of ANTASARI's blended learning model

\begin{tabular}{|c|c|}
\hline Learning Step & Implementation \\
\hline Auditory, & $\begin{array}{l}\text { The activity begins with gathering teachers and students in a virtual classroom using Google Meet } \\
\text { or Zoom Meeting. At this meeting, the teacher uses audio to provide a detailed explanation of the } \\
\text { substance of the physical activities that have been carried out. Explanations can be done in person } \\
\text { or using a voice recording. The explanations are supported by videos to provide more concrete } \\
\text { knowledge to students. } \\
\text { The teacher will present as many questions and answer activities as possible to give students the } \\
\text { opportunity to answer questions and provide arguments, the teacher will also provide opportunities } \\
\text { for students to provide answers to other students' questions so that various answers emerge. } \\
\text { Students are required to present answers in the form of logical facts based on the material being } \\
\text { discussed } \\
\text { This activity is certainly inseparable from training students to raise a lot of questions, because the } \\
\text { teacher's explanation will provoke students to express their curiosity about the problems that occur } \\
\text { and provoke students to prepare solutions that will be given. } \\
\text { The teacher will add activities to give students the opportunity to evaluate various ideas given to }\end{array}$ \\
\hline
\end{tabular}




\begin{tabular}{|c|c|}
\hline Learning Step & Implementation \\
\hline & $\begin{array}{l}\text { distinguish between relevant arguments and irrelevant arguments, until finally giving all students } \\
\text { the opportunity to conclude ideas } \\
\text { The activity begins with gathering teachers and students in a virtual classroom using Google Meet } \\
\text { or Zoom Meeting. At this meeting, the teacher uses audio to provide a detailed explanation of the } \\
\text { substance of the physical activities that have been carried out. Explanations can be done in person } \\
\text { or using a voice recording. The explanations are supported by videos to provide more concrete } \\
\text { knowledge to students. } \\
\text { The teacher will present as many questions and answer activities as possible to give students the } \\
\text { opportunity to answer questions and provide arguments, the teacher will also provide opportunities } \\
\text { for students to provide answers to other students' questions so that various answers emerge. } \\
\text { Students are required to present answers in the form of logical facts based on the material being } \\
\text { discussed } \\
\text { This activity is certainly inseparable from training students to raise a lot of questions, because the } \\
\text { teacher's explanation will provoke students to express their curiosity about the problems that occur } \\
\text { and provoke students to prepare solutions that will be given. } \\
\text { The teacher will add activities to give students the opportunity to evaluate various ideas given to } \\
\text { distinguish between relevant arguments and irrelevant arguments, until finally giving all students } \\
\text { the opportunity to conclude ideas }\end{array}$ \\
\hline $\begin{array}{l}\text { Negotiation } \\
\text { on Team, }\end{array}$ & $\begin{array}{l}\text { Students will be divided into several groups consisting of 3-4 people. students will be directed to } \\
\text { negotiate with friends in the group. Negotiation is a continuation of the observing and questioning } \\
\text { activities that have been raised in the Auditory activity. Negotiations started with the teacher } \\
\text { distributing number cards with different problems, the cards were given in the Whatsapp } \\
\text { application group in the form of pictures. The teacher will place students with the same problem in } \\
\text { a group, groups are formed with a special Whars App group which contains } 3-4 \text { students. The } \\
\text { teacher provides different factual problems for each group so that they will try to analyze each } \\
\text { problem presented. Students will negotiate in groups to formulate in detail what problems are } \\
\text { happening, what will happen if the problems are left alone. }\end{array}$ \\
\hline Analysis, & $\begin{array}{l}\text { The activity was continued by distributing student worksheets that offered several solutions that the } \\
\text { group of students would give. Students will be directed to analyze what will happen if the solution } \\
\text { is applied. To be more focused, analysis activities are equipped with worksheets that will guide } \\
\text { students to express their opinions and reasoning about the solutions given. Each group must } \\
\text { organize their learning experience so that they can find material concepts based on the problems } \\
\text { raised by the teacher. Analysis activities will formulate the results of reasoning that will be carried } \\
\text { out in physical activity. }\end{array}$ \\
\hline Somatic, & $\begin{array}{l}\text { Students will be directed to do physical activities that will train students to test the results of } \\
\text { reasoning about the solutions given with friends in the group. Physical activity consists of exploring } \\
\text { things that can be found in the child's environment. The group will investigate critically, } \\
\text { systematically, and logically so that they can formulate their own findings confidently. Before } \\
\text { students do physical activity, the teacher will provide clear directions starting from the activity } \\
\text { steps to the final result that will be obtained in the form of collecting data through information } \\
\text { gathering activities so that their critical thinking skills will be honed through this activity. The } \\
\text { teacher's explanation is given through the Google Meet or Zoom Meeting application so that all } \\
\text { students can listen to the detailed directions from the teacher. } \\
\text { Physical activity is carried out with various variations, the teacher can present experimental } \\
\text { activities by utilizing objects and objects around the child, not forgetting that the teacher will } \\
\text { involve the participation of the child's family at home to provide assistance in the experimental } \\
\text { process. But sometimes the experimental process is sometimes not necessarily suitable for every } \\
\text { topic of discussion, so it can be replaced by extracting information from various sources. Extracting } \\
\text { information is carried out to solve problems and prove the solutions put forward in the audio visual } \\
\text { activity based on the problems that are included in the topic of discussion }\end{array}$ \\
\hline $\begin{array}{l}\text { Administer } \\
\text { Information }\end{array}$ & $\begin{array}{l}\text { The results obtained from physical activity are used to carry out administered information activities } \\
\text { using the group work sheets. Group worksheets are distributed through the WhatsApp group, then } \\
\text { students who previously conducted the experiment individually are grouped into groups with the } \\
\text { feature of dividing participants into groups on the Zoom Meeting or google meet application. } \\
\text { Another alternative that teachers can do is to use WhatsApp media by forming small groups. }\end{array}$ \\
\hline
\end{tabular}




\begin{tabular}{|l|l|}
\hline Learning Step & \multicolumn{1}{c|}{ Implementation } \\
\hline Role Play and & $\begin{array}{l}\text { Students will work together to identify each item of question related to trying / gathering } \\
\text { information. Students will administer the information that has been obtained and hone their } \\
\text { knowledge and convey the meaning of the process of trying / digging up information on physical } \\
\text { active }\end{array}$ \\
\hline $\begin{array}{l}\text { Interaction } \\
\text { on Games }\end{array}$ & $\begin{array}{l}\text { This activity is filled with illustrating events related to subject matter that involve students as the } \\
\text { enthusiasm for students in practical activities through motion and words. The teacher prepares } \\
\text { scenarios before the start of learning to clarify the learning material to be delivered. The teacher } \\
\text { prepares a scenario before the start of learning to clarify the learning material that will be delivered } \\
\text { or given to students. The teacher asks each group representative to come forward to get information } \\
\text { on learning materials that will be delivered by the teacher. }\end{array}$ \\
\hline $\begin{array}{l}\text { At the end of the lesson before the teacher gives an award, students are invited to do a game. The } \\
\text { game is designed to be flexible, not bound by rules. The game is intended to provide fun activities } \\
\text { for students even though they are studying online at home. The game is designed to give students } \\
\text { the opportunity to interact with each other, either by using the WhatsApp, Google Meet or Zoom } \\
\text { Meeting applications. }\end{array}$ \\
\hline
\end{tabular}

The blended model step design that has been compiled is then validated by modeling experts, skills development experts and learning device experts with construct validity. Furthermore, the results of the validation of these three experts will show the feasibility level of the ANTASARI blended learning model which is used as a guide. The recapitulation of the results of the blended learning model validation from three experts can be seen in table 2 .

Table 2 The results of the validation of the ANTASAR blended learning model from the experts

\begin{tabular}{|c|l|c|c|}
\hline No. & \multicolumn{1}{|c|}{ Expert } & Validation Score & Percentage \\
\hline 1 & Learning model & 4.78 & $91 \%$ \\
\hline 2 & Skills development & 4.15 & $84.56 \%$ \\
\hline 3 & Learning Media & 4.39 & $86 \%$ \\
\hline \multicolumn{2}{|c|}{ Average } & 4.43 & $87.19 \%$ \\
\hline
\end{tabular}

The results of the validation of the three experts obtained an average percentage of $87.19 \%$ which was stated to be very feasible and usable. Even so, the validator provides comments and suggestions for revising some parts before they are used in learning. Improvements were made by describing in more detail the syntax of the blended learning model which consists of eight syntaxes, namely Auditory, Negotiation, Team, Analysis, Somatic, Administer Information, Role Play and Interaction on Games. This shows that the expert gave a positive response by answering with a minimum score of 4 in the 1-5 range on all the proposed assessment items.

The feasibility test of the learning model is accompanied by a feasibility test for the supporting factors for the blended learning model. Supporting factors for the ANTASARI blended learning model are learning tools including the Ecopedagogy integration syllabus and based on ecological awareness, soft and social skills. RPP uses the ANTASARI blended learning model, integrated teaching materials Ecopedagogy and based on ecological awareness, soft and social skills, evaluation based on ecological awareness, soft and social skills. The results of the validation by three experts on the learning device components met the very appropriate criteria with revisions, so revisions were made based on suggestions from experts.
Almost every component of the supporting factors received suggestions and input from the validator. These suggestions, among others, need to reconsider between activities and the allocation of learning time. According to experts, learning activities with learning objectives are carried out too much, so that it requires more time allocation. Revisions are made by improving the learning objectives at each meeting so that learning activities do not exceed the specified time allocation. This is in line with the results of research conducted by Mahnun[29] which states that in determining learning objectives, one must pay attention to available time management so that all learning objectives can be achieved optimally.

In addition, according to experts, there are discrepancies between lesson plans and teaching materials. Activities written in the student lesson plans only make study visits. This is because learning visits are carried out outside of lesson hours so that they do not enter into the learning activities written in the lesson plans, but the directions for conducting study visits are explained in the closing lesson plans. Kurnianingtyas (2016) states that study visits are more effective and efficient if they are carried out outside of class hours so that they do not interfere with class hours. Study visits outside of class hours are not limited by lesson hours so that students can explore more knowledge related to burnt batik and can take advantage of study time effectively and efficiently. 
The next stage is a small scale trial. Small-scale trials were carried out at SDN Pasar Lama 1 totaling 15 students. The data obtained from this small-scale trial was in the form of student responses regarding the ANTASARI blended learning model which consists of eight aspects with 24 statement numbers. Based on students' responses to the use of the ANTASARI blended learning model, it shows that the average score of 15 students is $84.5 \%$. These results indicate that the learning model developed is very good for learning. Furthermore, a large-scale trial was carried out using the experimental method. The experimental class and control class chosen were class $5 \mathrm{~A}$ and $5 \mathrm{~B}$. The experimental class consisted of 45 people and the control class had the number of greetings, namely 44 people. Just like a small-scale trial, in the form of student responses to the ANTASARI blended learning model which consists of eight aspects with 24 statement numbers. Based on student responses to the use of the ANTASARI blended learning model, it shows that the average score of 15 students is $89.4 \%$. In detail, student responses to large-scale trials can be seen in table 3 .

Table 3 Recapitulation of student responses to the ANTASARI blended learning model of experimental class students

\begin{tabular}{|c|l|c|}
\hline No. & \multicolumn{1}{|c|}{ Indicator } & Percentage $(\%)$ \\
\hline 1 & Encourage students to learn collaboratively & 91.1 \\
\hline 2 & Encourage students to learn collaboratively & 84.4 \\
\hline 3 & Presenting integrated learning content in the surrounding environment & 86.7 \\
\hline 4 & Train ecological awareness & 88.9 \\
\hline 5 & Train soft skills & 82.2 \\
\hline 6 & Train social skills & 88.9 \\
\hline 7 & Helping students to actively learn Average & 95.6 \\
\hline 8 & Show interest in learning & 97.7 \\
\hline \multicolumn{2}{c}{ a } \\
\hline
\end{tabular}

Student interest in learning using the ANTASARI blended learning model is very high. It can be seen from the student responses to indicator number eight which gets the highest percentage with very good criteria. This shows that students are interested in blended learning which is designed by incorporating elements of ecopedagogy and using the environment as a learning resource. This is based on the design of learning steps that are very suitable for the child's level of development, and designed with attention to the theory of meaningful learning. Learning is also designed to contain elements of collaboration, projects and games that make students more enthusiastic about learning, especially in the midst of the Covid-19 pandemic, which makes it impossible to interact directly with classmates.

This result has an impact on other indicators, each of which has a percentage of above $80 \%$. The indicators encourage students to learn collaboratively, showing that the criteria are very good. This is because the design of the blended learning model ANTASARI pays close attention to the interaction between students in groups. At first students never predict that online learning can be designed with group activities, but with very good direction from the teacher, group learning can be carried out optimally. If in face-to-face learning they can interact easily because it only requires communication between group members, in the ANTASARI blended learning model they are invited to argue with the media in the form of Zoom Meetings, Google Meet and WhatsApp groups. This does not take away the essence of collaborative or collaborative learnin The next aspect of presenting learning content containing ecopedics is also believed by students to have implemented it optimally. Students do not realize that learning is designed to include elements of environmental problems and ask them to provide alternative solutions to these various problems. In the ANTASARI blended learning model, researchers designed learning activities by including environmental objects to be observed and evaluated problems that were happening to find alternative solutions to problems.

The next indicator presents the integrated learning content of the surrounding environment, almost all students admit that learning is integrated in the surrounding environment. This is because learning activities are designed to contain environmental issues and students are given the opportunity to explore their surroundings. This activity supports blended learning, namely by combining face-toface online learning, instructional videos, online learning resources and utilizing the environment as a medium and learning resource.

In the indicators of training ecological awareness, soft skills and social skills, almost all students stated that they were increasingly mastering the skills developed in this learning. This is based on learning activities that are focused on developing these three skills. Starting from ecological awareness, students are presented with various environmental issues, this activity is in line with the learning themes, namely "our friendly environment". Students are presented with a problem and they have to collaborate to determine problem-solving strategies to suggest how the best problem solving according to them is. The skills developed in learning activities are exploring environmental issues, packaging action strategies to overcome environmental issues, acting skills on environmental issues,

Students are also trained to have critical thinking, problem-solving and independent skills in learning. This is because ANTASARI's blended learning is specifically 
designed to include activities that can develop critical thinking skills, problem solving and learning independence. Critical thinking skills are presented by training students to focus questions, analyze arguments, ask and answer about an explanation or challenge, conclude an idea or solution, interpret facts or conclusions or logical statements based on the information provided, evaluate and distinguish between strong arguments and relevant and weak or irrelevant arguments

Problem-solving skills are developed by presenting activities to demonstrate understanding the problem, organizing data and selecting relevant information in problem solving, choosing appropriate problem-solving approaches and methods, developing problem-solving strategies and solving non-routine problems. Learning independence is developed by presenting self-confidence training activities, encouraging students to actively participate in learning, hone student discipline, and consistently practice responsibility in participating in learning. Thus learning activities are designed to help students to actively learn

Other data obtained from large-scale trials, namely the assessment of learning implementation and student learning outcomes. The implementation of the activities of teachers and students in the learning process is presented in Figure 1:

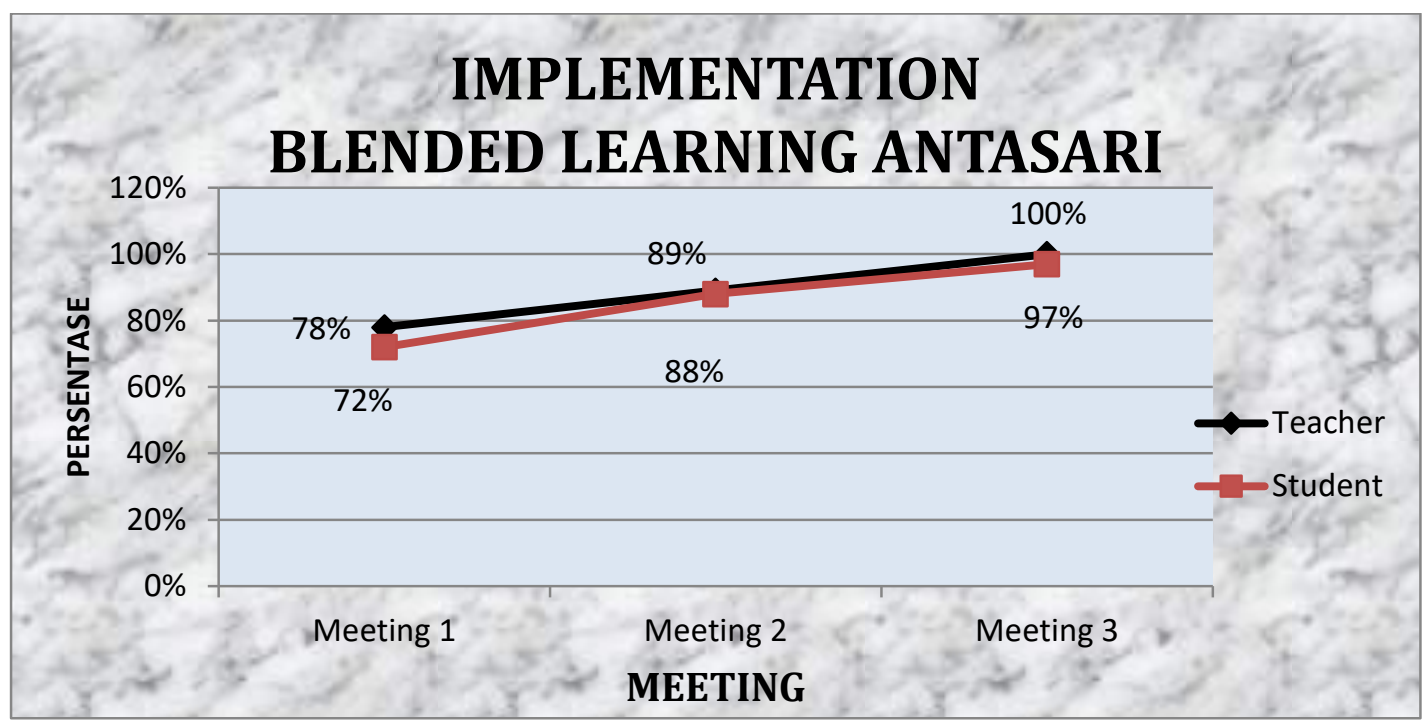

Figure 1 ANTASARI's Blended Learning Implementation Model

Overall the teacher can implement learning activities according to plan. Learning is more meaningful because students learn directly from the surrounding environment about topics related to the environment. The entire syntax of the learning model has been implemented according to the expected criteria. The teacher guides students to carry out Auditory, Negotiation, Team, Analysis, Somatic, Administer Information, Role Play and Interaction on Games activities. Each activity is carried out by paying attention to the narrative implementation of the specified syntax. This has been prepared in advance by the researcher and the homeroom teacher. Furthermore, the researcher acts as an observer to observe the implementation of each step of the model so that further comments are made if there are mistakes. Based on the results obtained, at the 1 st meeting the teacher still had problems in several steps, especially when presenting group learning online. So that it requires researchers to take part in providing direction to students. Especially for the implementation of learning by students, teachers and researchers collaborate to ensure that all students follow each learning step optimally. The direction is carried out by ensuring that students know the tasks in learning activities one by one.

Research in the large-scale trial phase also explores learning outcome data before and after using the ANTASARI blended learning model. In addition to learning outcomes, all skills were also analyzed for improvement using the $\mathrm{N}$-gain analysis to obtain an increase with an average of 0.59 in the "medium" category [30]. The results of $\mathrm{N}$ gain analysis on large-scale trials can be seen in Table 4 .

Table 4 N Gain of Big Scale trial on 3 Meetings

\begin{tabular}{|l|c|c|c|c|c|c|c|c|c|}
\hline \multirow{2}{*}{ Result } & \multicolumn{9}{c|}{ Category N Gain (\%) } \\
\cline { 2 - 13 } & \multicolumn{3}{|c|}{ Meeting 1 } & \multicolumn{3}{c|}{ Meeting 2 } & \multicolumn{3}{c|}{ Meeting 3 } \\
\hline & Low & Middle & High & Low & Middle & High & Low & Middle & High \\
\hline Knowledge & 61.2 & 29.4 & 9.4 & 21.2 & 52.1 & 26.7 & 0.0 & 4,4 & 85.6 \\
\hline Ecological awareness & 67.4 & 25.9 & 6,7 & 16.3 & 45.3 & 38.4 & 3,2 & 21.2 & 75.6 \\
\hline Problem Solving & 58.6 & 32.6 & 8.8 & 19.4 & 31.4 & 49.2 & 3,4 & 12.4 & 84.2 \\
\hline
\end{tabular}




\begin{tabular}{|l|c|c|c|c|c|c|c|c|c|}
\hline Critical Thinking & 66.8 & 25 & 8.2 & 18.3 & 33 & 48.7 & 4,1 & 14.6 & 81.3 \\
\hline Collaboration & 69.2 & 24.3 & 6.5 & 19.8 & 30 & 50.2 & 4,4 & 15.0 & 80.6 \\
\hline Independence & 68.1 & 24.7 & 7,2 & 21.2 & 30.1 & 48.7 & 2,2 & 16.4 & 81.4 \\
\hline Negotiation & 67.4 & 23.3 & 9.3 & 22.1 & 32.6 & 45.3 & 2,3 & 20.1 & 77.6 \\
\hline Analytical Thinking & 52.1 & 39.1 & 8.8 & 15.6 & 38 & 46.4 & 3.0 & 19.8 & 77.2 \\
\hline
\end{tabular}

The increase in the value of knowledge is dominated by the "high" category because the learning presented provides very high motivation to students. The learning process is also not dominated by the transfer of knowledge in the form of theory, but students are brought to participate in learning with a variety of collaborative and independent information gathering activities. Students are also led to explore various problems that occur around them, so that they are not required to memorize theories that make learning less meaningful. A significant increase also occurred in Ecological awareness, in a short time students were able to acquire these skills with intensive guidance from teachers and researchers. Learning is also directed at extracting information on problems that arise in their environment or that are familiar among them.

The activity was continued by finding alternative solutions to problems with colleagues in the group. This activity is also designed to be as attractive as possible even though it is only carried out online via the Zoom Meeting page, Google Meet or WhatsApp. This becomes a new routine for students so that it provokes student motivation and has an impact on increasing the quality of learning significantly. The critical thinking aspect in this research has also improved significantly. This is because learning is packaged with directions following the indicators of critical thinking skills. Students are also guided to do critical thinking processes intensively. Students are guided to identify different ways of doing critical analysis and developing questions and answers from multiple angles. With guidance from teachers and researchers,

An aspect that is no less important in this research is problem solving which has also increased significantly. This is because all indicators of problem solving skills are discussed one by one and developed for all students through the guidance of teachers and researchers. All students feel challenged to explore the problems that occur and look for alternative solutions to problems with friends in the group. Teachers and researchers give appreciation and reinforcement to students' ability to explore and solve problems, even though the results obtained are not yet perfect. This appreciation and reinforcement from the teacher also provokes student motivation to always try and try without fear of mistakes.
Learning is also directed to grow Independence. This can be seen from the percentage acquisition in the high category which dominates. This is because learning is provided with clear directions and communicative learning resources and contains detailed narrative directions for various activities, making students less dependent on teachers. A very encouraging condition was that at the third meeting the students were exploring alternative solutions to problems that did not require teacher guidance. They are very enthusiastic to argue to contribute ideas to solve the current problem.

A significant increase also occurred in the collaboration aspect, almost all students obtained very good criteria. This is because the learning process prioritizes group learning and fosters a collaborative spirit in students. All students are guided not only to share assignments in groups, but to cultivate collaboration values in each student. Students are encouraged intensively to care for each other and have responsibility for group assignments. Students are also given the opportunity to interact and communicate with each other so that the problem solving carried out in the group runs optimally. This activity also fosters negotiation skills. All students are trained to prioritize common interests and prioritize group interests. Coupled with the development of communication skills both individually and in groups.

The data obtained from this large-scale trial showed positive results, so the next step was implementation (deployment). The implementation was carried out in the experimental class and the control class, the effectiveness of the ANTASARI blended learning model was known from the difference in the increase in student learning outcomes in the experimental class and the control class in the aspects of knowledge, critical thinking skills, problem solving and ecological awareness. The effectiveness of using the blended learning model can be seen from the classical completeness and the difference in the analysis of the increase in pretest and posttest scores for both the experimental class and the control class. The results of classical completeness in the experimental class and control class can be seen in Table 5 .

Table 5 Classical Completeness in The Experimental Class and Control Class

\begin{tabular}{|c|c|l|c|c|c|}
\hline \multirow{2}{*}{ Class } & $\begin{array}{c}\text { Number of } \\
\text { Students }\end{array}$ & \multicolumn{1}{c|}{ Result } & Pretest Average & Posttest Average & $\begin{array}{c}\text { Completeness } \\
\text { Percentage } \\
(\%)\end{array}$ \\
\hline \multirow{4}{*}{ Experiment } & \multirow{3}{*}{45} & Knowledge & 45.95 & 89.47 & 91.94 \\
\cline { 3 - 6 } & & Critical Thinking & 22.79 & 84.42 & 87.43 \\
\cline { 3 - 6 } & & Problem Solving & 39.81 & 88.5 & 90.25 \\
\cline { 3 - 6 } & Ecological awareness & 49.51 & 82.67 & 86.11 \\
\hline
\end{tabular}




\begin{tabular}{|c|c|l|c|c|c|}
\hline \multirow{3}{*}{ Control } & Knowledge & 62.16 & 64.25 & 36.00 \\
\cline { 3 - 6 } & \multirow{4}{*}{45} & Critical Thinking & 61.7 & 64.33 & 31.24 \\
\cline { 3 - 6 } & Problem Solving & 52.21 & 58.81 & 11.56 \\
\cline { 3 - 6 } & Ecological awareness & 55,80 & 55,80 & 12.41 \\
\hline
\end{tabular}

Table 5 shows that the classical completeness of the experimental class and the control class is different. For the experimental class as a whole, it has achieved success indicators, namely $\geq 70 \%$ of students who took the posttest test had met the indicators of success. This is because all students feel helped to master the concept of our friend's environmental theme by using the ANTASARI blended learning model in the midst of the Covid-19 pandemic. Whereas for the control class $\leq 70 \%$ of students met the indicators of success after participating in the lesson. This is because the control class does not get the same treatment as the experimental class so that the results obtained by the control class are not as good as the results obtained by the experimental class.

Learning in the control class uses a cooperative learning model with a scientific approach. Teaching materials used by the control class are student handbooks circulating in school, so that students' knowledge of the environment is limited. Students in the control class obtained material only from the teacher who conducted lectures. Whereas in the experimental class the learning uses the ANTASARI blended learning model which directs students to be able to learn more meaningfully with diverse and innovative learning activities. In addition, the teaching materials used in the experimental class are teaching materials that contain critical thinking skills, problem solving, social skills and ecological awareness, so that students feel helped in learning.

In this study also found significant differences in each skill developed. The results of developing students' creative thinking skills in each indicator are described in Table 6.

Table 6 Ecological Awareness Criteria

\begin{tabular}{|l|c|c|}
\hline \multicolumn{1}{|c|}{ Ability Indicators Ecological Awareness } & \multicolumn{2}{|c|}{ Ability Criteria Ecological Awareness } \\
\cline { 2 - 3 } & Experiment & Control \\
\hline Explore environmental issues & High & Middle \\
\hline $\begin{array}{l}\text { Make planning action strategies to address } \\
\text { environmental issues }\end{array}$ & High & Low \\
\hline Act on environmental issues, & High & Ver High \\
\hline attitude and a good personality attitude & High & Ver High \\
\hline
\end{tabular}

Table 6 shows that there is a very significant difference between the experimental class and the control class. Ecological awareness development is carried out by including content about environmental conditions that occur in student areas in teaching materials. Development is carried out starting from providing activities to explore the contents of environmental issues, followed by training students to have the ability to package action strategies to overcome environmental issues, to act on environmental issues and to have a good attitude and personality attitude. The experimental class obtained better criteria than the control class. This is because the learning is packaged with the ANTASARI blended learning model. In the ANTASARI blended learning model, auditory activity steps are presented that train students to raise many questions, because the teacher's explanation will provoke students to express their curiosity about the problems that occur and provoke students to prepare solutions to be given. In addition, the development of ecological awareness was raised in Somatic activities. This activity is packed with physical activities containing exploration activities for things that can be found in the child's environment. The group will investigate critically, systematically, and logically so that they can formulate their own findings confidently. This activity is packed with physical activities containing exploration activities for things that can be found in the child's environment. The group will investigate critically, systematically, and logically so that they can formulate their own findings confidently. This activity is packed with physical activities containing exploration activities for things that can be found in the child's environment. The group will investigate critically, systematically, and logically so that they can formulate their own findings confidently.

Table 7 Critical Thinking Ability Criteria

\begin{tabular}{|l|c|c|}
\hline \multicolumn{1}{|c|}{ Critical Thinking Ability Criteria } & \multicolumn{2}{c|}{ Critical Thinking Ability Criteria } \\
\cline { 2 - 3 } & Experiment & Control \\
\hline Focusing questions, analyzing arguments, & high & low \\
\hline Ask and answer about an explanation or challenge; & high & Very low \\
\hline ; Ability to conclude an idea or solution; & high & Very low \\
\hline $\begin{array}{l}\text { Interpret facts or conclusions or logical statements } \\
\text { based on the information provided; }\end{array}$ & high & \\
\hline
\end{tabular}




\begin{tabular}{|l|c|c|}
\hline $\begin{array}{l}\text { Evaluating, distinguishing between strong and relevant } \\
\text { arguments and arguments that are weak or irrelevant }\end{array}$ & high & Very low \\
\hline
\end{tabular}

Table 7 shows that there is a very significant difference between the experimental class and the control class. In the experimental class, the development of critical thinking is included in several learning steps. This activity develops indicators of focusing questions, analyzing arguments, asking and answering questions about an explanation or challenge, the ability to conclude an idea or solution, interpret facts or conclusions or logical statements based on the information provided, evaluate, distinguish between strong and relevant arguments and weak or irrelevant arguments. The development of each item of critical thinking skills begins in the Auditory activity. The teacher presents as many question and answer activities as possible to give students the opportunity to answer questions and provide arguments, the teacher will also provide opportunities for students to provide answers to other students' questions so that various answers emerge. Students are required to present answers in the form of logical facts based on the material being discussed. This skill is also displayed in the Analysis step. Students will be directed to analyze what will happen if the solution is applied.

Table 8 Problem Solving Ability Criteria

\begin{tabular}{|l|c|c|}
\hline \multicolumn{1}{|c|}{ Problem Solving Ability Criteria } & Experiment & Control \\
\cline { 2 - 3 } $\begin{array}{l}\text { Ability to demonstrate understanding of } \\
\text { the problem. }\end{array}$ & High & middle \\
\hline $\begin{array}{l}\text { Ability to organize data and select } \\
\text { relevant information in problem solving. }\end{array}$ & High & low \\
\hline $\begin{array}{l}\text { Ability to choose appropriate problem- } \\
\text { solving approaches and methods. }\end{array}$ & middle & Very low \\
\hline $\begin{array}{l}\text { Ability to develop problem solving } \\
\text { strategies. }\end{array}$ & High & Very low \\
\hline $\begin{array}{l}\text { Ability to solve problems that are not } \\
\text { routine. }\end{array}$ & High & Very low \\
\hline
\end{tabular}

Table 8 shows that there is also a significant difference between the experimental class and the control class in problem solving skills. In the experimental class, the development of problem-solving skills is included in several learning steps. This activity develops indicators showing understanding of the problem, organizing data and selecting relevant information in problem solving, choosing appropriate problem-solving approaches and methods, developing problem-solving strategies, solving non-routine problems. The development of each item of critical thinking skills begins in the Auditory activity. train students to raise lots of questions, because the teacher's explanation will provoke students to express their curiosity about the problems that occur and provoke students to prepare solutions to be given.
The teacher will add the activity to give students the opportunity to evaluate the various ideas given to distinguish between relevant arguments and irrelevant arguments, until finally giving all students the opportunity to conclude ideas. This skill is also displayed in the Analysis step. Each group must organize their learning experience so that they can find material concepts based on the problems raised by the teacher. Analysis activities will formulate the results of reasoning that will be carried out in physical activity. The development of problemsolving skills is also raised in Somatic activities which will train students to test the results of reasoning about solutions given with friends in the group. Physical activity consists of exploring things that can be found in the child's environment. The group will investigate critically.

Table 9 Independence in learning

\begin{tabular}{|l|c|c|}
\hline \multirow{2}{*}{\multicolumn{1}{|c|}{ Responsibility in learning }} & \multicolumn{2}{c|}{ Responsibility in learning } \\
\cline { 2 - 3 } & Experiment & control \\
\hline Confidence & High & middle \\
\hline Active in learning & High & low \\
\hline Discipline in learning & High & Very low \\
\hline Responsibility in learning & High & low \\
\hline
\end{tabular}

Table 9 shows that there is also a significant difference between the experimental class and the control class in problem solving skills. In the experimental class, the development of problem-solving skills is included in several learning steps. This activity develops indicators of self-confidence, active learning, discipline and responsibility. This activity appears in almost all learning steps, namely Auditory, Negotiation on Team, Analysis, Somatic, Administer Information, Role Play and Interaction on Games. This is the basis for the 
Table 10 Cooperation Capability Criteria

\begin{tabular}{|l|c|c|}
\hline \multirow{2}{*}{ Cooperation Ability Indicator } & \multicolumn{2}{c|}{ Cooperation Capability Criteria } \\
\cline { 2 - 3 } & Experiment & Control \\
\hline Work Collaboratively & High & middle \\
\hline Contribute in groups & middle & low \\
\hline $\begin{array}{l}\text { Ability to convey information to each other } \\
\text { Analytical thinking }\end{array}$ & middle & Very low \\
\hline Concern & & \\
\hline Responsive & High & Very low \\
\hline Participation & middle & Very low \\
\hline
\end{tabular}

Table 10 shows that there is also a significant difference between the experimental class and the control class in problem solving skills. In the experimental class, the development of cooperation skills was included in several learning steps. This activity develops indicators of working collaboratively, contributing in groups, the ability to share communication information with one another, caring, responsiveness and participation. The development of each item of critical thinking skills begins with the Analysis, Somatic, Administer Information and Role Play activities. All of these activities are carried out in groups, teachers and researchers guide students to always prioritize common interests in working collaboratively. The teacher also ensures that all group members contribute to providing assistance. exchange information and knowledge and foster a caring attitude towards assignments in the group. They are given reinforcement to feel they have a responsibility to care for each other, respond to any questions and statements from friends and prioritize participation even though they do not have a big influence in the group.

Table 11 Communication Ability Criteria

\begin{tabular}{|l|c|c|}
\hline \multicolumn{1}{|c|}{ Communication Ability Indicator } & \multicolumn{2}{c|}{ Communication Ability Criteria } \\
\cline { 2 - 3 } & Experiment & Control \\
\hline Receive and give information & High & Moderate \\
\hline express opinions or arguments in the group & High & Low \\
\hline $\begin{array}{l}\text { Responding to statements from friends in the } \\
\text { group during the discussion }\end{array}$ & High & Very low \\
\hline explain what will and has been done in the group & High & Very low \\
\hline $\begin{array}{l}\text { Receiving information provided by a group of } \\
\text { friends well and giving a positive response even } \\
\text { though there are differences of opinion }\end{array}$ & & \\
\hline
\end{tabular}

Table 11 shows that there is also a significant difference between the experimental class and the control class in communication skills. In the experimental class, the development of communication skills was included in each learning step. This activity develops indicators of giving and receiving information, expressing opinions or arguments in the group, responding to statements from friends in the group during discussions, explaining what will and has been done in the group, accepting information provided by group friends properly and giving positive Responses even though it occurs differences of opinion. these activities are always raised in every step of the learning. The teacher also ensures that all group members exchange information and knowledge even if only in two to three sentences.

Table 12 Negotiation Ability Criteria

\begin{tabular}{|l|c|c|}
\hline \multicolumn{2}{|c|}{ Negotiation Ability Indicator } & \multicolumn{2}{|c|}{ Negotiation Ability Criteria } \\
\cline { 2 - 3 } & Experiment & Control \\
\hline $\begin{array}{l}\text { The ability to separate personal } \\
\text { feelings from the problem at hand }\end{array}$ & Hight & Middle \\
\hline $\begin{array}{l}\text { Ability to focus on interests not } \\
\text { positions. }\end{array}$ & Middle & low \\
\hline Ability to collect multiple choices & Middle & Very low \\
\hline
\end{tabular}




\begin{tabular}{|l|l|l|}
\hline before making a final decision. & & \\
\hline $\begin{array}{l}\text { Ability to ensure that results are based } \\
\text { on objective criteria. }\end{array}$ & High & Very low \\
\hline
\end{tabular}

Table 11 shows that there is also a significant difference between the experimental class and the control class in negotiation skills. In the experimental class, the development of negotiation skills is included in a special learning step, namely negotiation on team. This activity develops indicators of separating personal feelings from the problem at hand, focusing on interests not positions, collecting several options before making a final decision, ensuring that the results are based on objective criteria. This skill was developed by the teacher distributing number cards with different problems, the cards were given in the Whatsapp application group in the form of pictures. The teacher will place students with the same problem in a group, groups are formed with a special What App group which contains 3-4 students. The teacher provides different factual problems for each group so that they will try to analyze each problem presented. Students will negotiate in groups to formulate in detail what problems are happening, what will happen if the problems are left alone.

\section{DISCUSSION}

ANTASARI's blended learning model is an idea of overcoming learning problems during the COVID-19 pandemic. Even though the country is still in a state of a virus outbreak, learning in schools cannot be sacrificed. The learning process must continue, either in the form of knowledge transfer or skills development. ANTASARI's blended learning model is an alternative solution for developing student skills even though learning is only carried out from home. This is in line with the results of the research by Noorhapizah, Agusta and Pratiwi (2020) that the learning process must run optimally even though conditions require teachers and students to interact online from their respective homes. The ANTASARI blended learning model is also an alternative solution for developing student skills that teachers can use as a reference, because according to research by Noorhapizah, Agusta and Pratiwi (2020) most teachers still have not mastered the concept of skills that must be developed in elementary school students and have not been able to package learning loaded these skills. The skill that must be developed to ensure the lives of future generations is ecological awareness. Ecological awareness must be developed from an early age, the perfect time to cultivate a sense and sensitivity to care for the environment is at the elementary school age. Primary school students as the next generation of life in the future must have the ability to protect and preserve the environment Agusta and Pratiwi (2020) most teachers still have not mastered the concept of skills that must be developed in elementary school students and have not been able to package learning loaded these skills. The skill that must be developed to ensure the lives of future generations is ecological awareness.
Ecological awareness must be developed from an early age, the perfect time to cultivate a sense and sensitivity to care for the environment is at the elementary school age. Primary school students as the next generation of life in the future must have the ability to protect and preserve the environment Agusta and Pratiwi (2020) most teachers still have not mastered the concept of skills that must be developed in elementary school students and have not been able to package learning loaded these skills. The skill that must be developed to ensure the lives of future generations is ecological awareness. Ecological awareness must be developed from an early age, the perfect time to cultivate a sense and sensitivity to care for the environment is at the elementary school age. Primary school students as the next generation of life in the future must have the ability to protect and preserve the environment the perfect time to cultivate a sense and sensitivity to care for the environment is at the elementary school age. Primary school students as the next generation of life in the future must have the ability to protect and preserve the environment the perfect time to cultivate a sense and sensitivity to care for the environment is at the elementary school age. Primary school students as the next generation of life in the future must have the ability to protect and preserve the environment [31][32], so that currently learning must contain content on environmental issues and students are expected able to provide alternative solutions to the problems that occur [31]. Starting from the findings of a literature review which suggests that currently human knowledge about the need for life between humans and nature, most humans do not have a high awareness of the obligation to strive to maintain balance, harmony and harmony in nature [31,33].

In addition, concern for the environment becomes an attitude and character that will encourage humans to strive to prevent and overcome various types of damage to the natural environment, especially the environment around them $[33,34,35,36,37,38,39]$. They will work on various innovations to regenerate the natural damage that has occurred. To realize this, it is necessary to make efforts to develop environmental awareness in students from an early age through learning that contains environmentbased content or we are known as ecopedagogy $[39,40,41,42]$. Ecopedagogy will foster a new paradigm in developing awareness of the need to preserve the natural environment through ecopedagogy-based education in instilling ecological awareness and character in the younger generation.

The above problems become the base for developing ANTASARI's blended learning. This blended learning model is designed to include elements of environmentbased learning. Starting from discussing issues of environmental problems, utilizing the environment as a learning resource, giving students the opportunity to explore the natural environment around the house, be 
creative with living things or waste from living things, find solutions to environmental problems, provide media and learning resources by loading based content. local wisdom, regional characteristics and the surrounding environment. The development of the ANTASARI model is also based on the demand to produce elementary school graduates who are able to think critically. Critical thinking skills have an impact on students' ability to think deeply and consider various solutions to problems to produce fast, precise and accurate solutions [43,44,44,45,46,47,48,49]. Shiva who is accustomed to being trained in critical thinking will have speed and accuracy in solving problems and getting used to arguing or communicating with various points of view according to the context of the problem [50,51,52,53,54,55,56,57,58,59].

Critical thinking skills are very important to be developed and integrated in learning. This is in line with the goals of education in elementary schools, namely being able to think critically. But in reality, the implementation of learning in schools tends to pay less attention to critical thinking skills, especially in the midst of the Covid-19 pandemic because teachers and students cannot interact directly. Therefore, the learning paradigm should shift from conventional learning which emphasizes low-level thinking skills to higher-order thinking skills, especially critical thinking, which is the basis for students to be able to develop higher-order thinking $[60,61,62,63,64]$.

Thinking is an active, orderly, and meaningful process by which we understand the world. Critical thinking is thinking to systematically investigate the thought process itself, which means not only thinking on purpose, but also examining how we and others use evidence and logic $[65,66,67,53,68,69,63,64]$. Critical thinking is the most important part in the learning process because critical thinking will create a younger generation who are able to interpret, analyze, conclude, evaluate, explain and selfregulate both in education and in the general field $[64,64,64,70]$. The importance of critical thinking skills is a strong foundation for researchers to package the ANTASARI blended learning model, several learning steps including the development of critical thinking skills, namely Auditory, Analysis, and Somatic activities.

Apart from focusing on improving critical thinking skills, the development of the ANTASARI blended learning model also has the advantage of increasing student learning independence. Studies in a period of nearly 10 years report that students who have high learning independence show a tendency to learn better under their own supervision than in program supervision, are able to monitor, evaluate, and organize their learning effectively, save time in completing assignments and organize learning and time efficiently $[71,72,73,74,75,76,77,78,79]$.

Learning independence is one of the skills developed in the 2013 curriculum. The 2013 curriculum not only encourages the development of learning outcomes in the cognitive component, but affective aspects should be developed in students simultaneously and proportionally, one of which is independence in learning. Independent learning does not mean learning alone without the help of others. Some experts define self-regulated learning (abbreviated as SRL) in different ways[80,81,79,82, 83]. However, this different definition contains three main steps in SRL, namely: a) designing its own learning according to its objectives, b) choosing a strategy and implementing its learning plan, and c) monitoring its own learning progress, evaluating its learning outcomes and comparing it with certain standards [80,81,79,83,84,85,86,87].

The development of independent learning is intended so that students have the ability to monitor their own behavior to compare their own positions with certain standards and be able to respond themselves to both positive and negative responses. Students who have independence in learning will have intrinsic learning initiative and motivation, have the habit of diagnosing learning needs, are able to set learning goals or targets, monitor, organize, and control learning, view difficulties as challenges, utilize and find relevant sources, choose, apply learning strategies, evaluating learning processes and outcomes[88,89,90,91,92, 93,94,95,96,97,83]. Thus, the ANTASARI blended learning model contains various learning steps in which it provides independent guidance in learning. The development of independent learning can be found in almost all learning steps, namely Auditory, Negotiation on Themes, Analysis, Somatic, Administer Information, Role Play to Interaction on Games. Each step of the ANTASARI blended learning model is designed to develop ecological awareness, soft and social skills that are interrelated in each learning step. Auditory's first learning step, in this step students will listen to the teacher's explanation using audio, the teacher will also build students' initial knowledge using video which aims to provide more concrete knowledge to students. Students will be invited to observe objects related to the learning topic.

The teacher gives students the opportunity to answer questions and provide arguments, the teacher will also provide opportunities for students to provide answers to other students' questions so that various answers emerge. Students are trained to present answers in the form of logical facts based on the material discussed. The teacher will add the activity to give students the opportunity to evaluate the various ideas given to distinguish between relevant arguments and irrelevant arguments, until finally giving all students the opportunity to conclude ideas This activity will train students to be able to think critically. Activities are designed to develop critical thinking indicators which consist of focusing questions, analyzing arguments, asking and answering questions about an explanation or challenge, concluding an idea or solution, interpreting facts or conclusions or logical statements based on the information provided, evaluating, differentiating between strong and relevant arguments and arguments that are weak or irrelevant $[66,43,51,67,60,53,68,62,44,98,45,62,46,47]$. This activity step is in line with previous research which states that critical thinking can be developed by asking questions or giving students the opportunity to make questions from observations $[54,99,56,63]$, giving students the opportunity to explore the problems that are happening from the 
observations [59,61], opening students' insights using concrete and various objects $[52,60,100,57,58]$, using the surrounding environment as an object of observation $[53,68,70]$, involving students providing arguments to answer questions $[52,53,101,64,49,67]$.

In addition, the development of ANTASARI's blended learning is one of the strategies to train critical thinking using mobile learning technology. This is in line with the research results which show that using mobile learning can develop students' critical thinking $[67,50,55,69]$, this blended learning model also trains students. to be able to interpret, analyze, conclude, evaluate, explain and selfregulation (self-efficacy) in both the education and general fields $[102,103,104,96]$.

ANTASARI's blended learning step is continued with Negotiation on Team, students will negotiate with friends in the group. Negotiations started with the teacher distributing number cards with different problems, the cards were given in the Whatsapp application group in the form of pictures. Students will negotiate in groups to formulate in detail what problems are happening, what will happen if the problems are left alone. Students are given experiences to focus attention on the problem at hand, focus on the interests of finding solutions, gather some information to choose before making a final decision, ensure that the results are based on objective criteria. Students will also be equipped with the skills to contribute in groups and share communication information.

Negotiation skills can be formed through activities with groups to explore information about problems [105], involving students directly to feel the problems that are happening by sharing information [106], providing opportunities for students to express opinion and test the understanding of each group member with spontaneous questions but provide opportunities for other students to help friends who are being asked spontaneous questions [53,68,62,44,98,45,107], provides opportunities for students to share their experiences and suggest solutions based on reasoning and thinking about the impact that will occur if alternative solutions are implemented [108], students are given the freedom to explore opinions through experiments in groups and involve the whole $h$ group members to participate in each other $[4,109]$.

The activity was continued with the Analysis activity. In this activity, the teacher provides learning content that is more specific to exploring environmental issues associated with the South Kalimantan area. Students will be asked to analyze what will happen if the problem is left alone. Then students and groups will discuss the best solution to the problem being discussed. Furthermore, students will be directed to analyze what will happen if the solution is applied. To be more focused, analysis activities are equipped with worksheets that will guide students to express their opinions and reasoning about the solutions given. Each group must organize their learning experience so that they can find material concepts based on the problems raised by the teacher.

This activity also focuses on fostering student ecological awareness because activities are packaged through exploring environmental issues, exploring environmental issues will foster mastery of the concept of environmental education $[110,40,41,42]$. creating a learning atmosphere that is more interesting, more fun, more interactive, less boring, effective and efficient as well as developing a character that loves the environment and appreciates natural wealth $[111,34,35,36,37,39]$. This activity is also structured by packaging action strategies to overcome environmental issues, this activity is able to develop skills in managing the environment [40,112,36], can develop critical thinking skills, improve motivation and problemsolving skills $[113,114,115]$ PENDIPA: Journal of Science Education - Bengkulu University Vol 1, No 1 (2017), besides that it can improve reflective thinking and argumentation skills [36,116], this activity can also develop analytical skills, evaluation skills, and creative abilities [117,118,119,120] Journal of Equatorial Education and Learning Vol 4, No 3 (2015) Tanjung pura University. And Vol 8, No. 1 (2019). This activity is also coupled with acting on environmental issues and a good personality attitude, this activity can develop critical thinking, analytical, creative and reflective thinking skills $[121,122,36,114,123]$.

In the same activity, students will be trained to have creative problem-solving skills, because the problems given in detail and contextually can train students to provide creative and logical solutions to solve problems $[124,125,126,127,128,129]$. Students will carry out activities to organize data and select relevant information in problem solving which will train logical, creative, systematic and analytical thinking skills [130,131,132,133,134,135,136], choosing appropriate problem-solving approaches and methods, developing problem-solving strategies that allow students to provide creative and different ideas from other groups $[137,138,139,140,141,142,128]$. This activity combines direct data mining in their environment and web based learning. Web-based learning activities often involve information searching tasks since the learning environment is connected with information sites worldwide and video $[143,144]$, this activity will also improve students' reading skills $[145,146,147]$.

In the same activity, students will be trained to have creative problem-solving skills, because the problems given in detail and contextually can train students to provide creative and logical solutions to solve problems $[124,124,126,127,128,129]$. Students will carry out activities to organize data and select relevant information in problem solving that will train logical, creative, systematic and analytical thinking skills $[130$, $131,132,132,134,135,136]$, choosing appropriate problemsolving approaches and methods, developing problemsolving strategies that allow students to provide creative and different ideas from other groups [137] $[138,139,140,141,142,135]$. This activity combines direct data mining in their environment and web based learning. Web-based learning activities often involve information searching tasks since the learning environment is connected with information sites worldwide and video $[143,144]$, these activities will also improve students' reading skills [145,145,146,147]. 
Carried out by providing and receiving information, conveying opinions or arguments within the group in solving problems that will hone students' communication skills with innovations carried out using virtual technology $[148,149,150,151,152]$, responding to statements from friends in the group during the discussion, explaining what will and has been done in the group [153,154] received information provided by a group of friends well and responded positively even though there were differences of opinion [155]. This activity will also train students' independence in learning to grow self-confidence, active in learning, discipline and responsibility $[156$, 157,158,159]. Analysis activities will also train students' collaboration skills starting from working collaboratively $[105,107]$, contributing to groups, conveying information clearly $[108,4]$, communicate with each other, care for all group members $[109,160]$ responds to every group need and participates fully in various steps to solve problems $[161,162]$. The activity continued with Somatic. Students will be directed to do physical activities that will train students to test the results of reasoning about the solutions given with friends in the group. Physical activity consists of exploring things that can be found in the child's environment. The group will investigate critically, systematically, and logically so that they can formulate their own findings confidently. The teacher will provide an explanation through the Google Meet or Zoom Meeting application so that all students can listen to detailed directions from the teacher.

This activity is also a continuation of the development of ecological awareness that can train students to package action strategies to overcome environmental issues and implement solutions $[163,164,165]$. Somatic activities again train problem-solving skills that focus on data organizing skills and selecting relevant information in problem solving, implementing appropriate problemsolving approaches and methods $[137,138,139]$.

Somatic activities will also hone students' communication skills through giving and receiving information, conveying opinions or arguments within the group [156,157], responding to statements from friends in the group during discussions, explaining what will and has been done in the group, receives information provided by group friends well and gives a positive response despite differences of opinion [150,151,152].

The activity continued with Administer Information. Students will work together to identify each item of question related to trying / gathering information. Students will administer the information that has been obtained and hone knowledge and convey the meaning of the process of trying / digging up information on physical activity. This activity will also train students' independence in learning to grow self-confidence $[156,157,158,166,159]$, is active in learning, discipline and responsibility. Administer information activities will also train students' collaboration skills starting from working collaboratively online $[167,168,169]$, contributing in groups, conveying information clearly $[170,171]$, communicates with each other, cares for all group members $[172,173]$, responds to every group need and participates fully in various steps to solve problems [174,175,176,177].

Activities continued with Role Play activities. This activity is filled with illustrating events related to subject matter that involve students as the main actors in it. The delivery of illustrations is done in the form of a story as well as provoke enthusiasm for students in practical activities through movements and words. The teacher prepares a scenario before the start of learning to clarify the learning material that will be delivered or given to students. The teacher asks each group representative to come forward to get information on learning materials that will be delivered by the teacher.

The main objective of this activity is to train students' communication skills $[148,149]$ This activity also fosters students' concern for the environment, because role play content will focus on skills to act on environmental issues and respond to environmental damage that occurs to feel how environmental conditions are from two sides $[148,149,150]$ students can weigh the best attitude to respect the environment [148,149] Role play activities can also train student cooperation, because role play activities involve working collaboratively, contributing to groups, convey information clearly, communicate with each other, care for all group members, respond to group needs and participate fully in various steps of group activities $[111,34,35,36,37,39]$.

\section{CONCLUSION}

a. the characteristic and implementation of the blended learning model ANTASARI consist of Auditory, Negotiation, Team, Analysis, Somatic, Administer Information, Role Play and Interaction on Games;

b. ANTASARI's blended learning model is appropriate to be used according to the results of the validation from 3 experts with validation percentage of learning steps get hich criteria, skills improvement get high criteria and teaching materials also get high criteria

c. ANTASARI's blended learning model is effective to be used in learning based on the results of evaluations using instruments of soft and social skills.

d. The improvement after implementation blended learning model, the students who are getting high criteria on ecological awareness, critical thinking, problem-solving, independence, collaboration, negotiation and communication from low criteria increase to high criteria more than $75 \%$.

\section{REFERENCES}

[1] Suparman and D. N. Husen, "PENINGKATAN KEMAMPUAN BERPIKIR KREATIF SISWA MELALUI PENERAPAN MODEL PROBLEM BASED LEARNING," J. ßIOêduKASI, vol. 3, no. 2, pp. 367-372, 2015.

[2] M. Tendrita, S. Mahanal, and S. Zubaidah, "Pemberdayaan Keterampilan Berpikir Kreatif 
melalui Model Remap Think Pair Share," Proceeding Biol. Educ. Conf. (ISSN 2528-5742), vol. 13, no. 1, pp. 285-291, 2016.

[3] A. Suriansyah and S. Mahriati, "Meningkatkan Hasil Belajar Konsep Sifat-Sifat Bangun Ruang dengan Model Pembelajaran Two Stay Two Stray dan Media Realia Siswa Kelas V SDN Pengambangan 8 Kota Banjarmasin," $J$. Paradig., vol. 11, no. 2, p. 118, 2016.

[4] A. R. Agusta, P. Setyosari, and C. Sa'dijah, "Implementasi Strategi Outdoor Learning Variasi Outbound untuk Meningkatkan Kreativitas dan Kerjasama Siswa Sekolah Dasar," J. Pendidik. Teor. Penelitian, dan Pengemb., vol. 3, no. 4, pp. 453-459, 2018.

[5] A. H. Panjaitan and E. Surya, "Creative Thinking (Berpikir Kreatif) Dalam Pembelajaran Matematika," 2017.

[6] Thompson, Crafting \& Executing Strategy; The Quest for Competitive Advantage (Sixteenth Edition). New York: Mc-Graw Hill International Editon, 2008.

[7] D. Zuchdi, Z. K. Prasetya, and D. M. S. Masruri, "Pengembangan Model Pendidikan Karakter Terintegrasi Dalam Pembelajaran Bidang Studi Di Sekolah Dasar," J. Cakrawala Pendidik., vol. 1, no. 3, pp. 1-12, 2010, doi: 10.21831/cp.v1i3.224.

[8] Hasratuddin, "Pembelajaran Matematika Sekarang dan yang akan Datang Berbasis Karakter," Didakt. Mat., vol. 1, no. 2, pp. 30-42, 2014, doi: 10.24815/jdm.v1i2.2059.

[9] E. Istianah, "Meningkatkan Kemampuan Berpikir Kritis Dan Kreatif Matematik Dengan Pendekatan Model Eliciting Activities (Meas) Pada Siswa Sma," Infin. J., vol. 2, no. 1, p. 43, 2013, doi: 10.22460/infinity.v2i1.23.

[10] Y. Y. Manafe, P. Setyosari, D. Kuswandi, and S. Ulfa, "Pengaruh Strategi Kerjasama Kelompok dan Efikasi Diri terhadap Hasil Belajar Keterampilan Teknikal," J. Pendidik. Hum., vol. 4, no. 3, pp. 152-162, 2016.

[11] E. Widiasworo, Strategi \& Metode Mengajar Siswa di Luar Kelas (OUTDOOR LEARNING) Secara Aktif, Kreatif, Inspiratif, \& Komunikatif. Yogyakarta: Ar-Ruzz Media, 2017.

[12] R. Ennis, "Critical Thinking: Reflection and Perspective Part 1," Inq. Crit. Think. Across Discip., vol. 26, no. 1, 2011.

[13] Kowiyah, "Kemampuan Berpikir Kritis," $J$. Pendidik. Dasar2, vol. 3, no. 5, pp. 175-179, 12AD.

[14] R. Mahmuzah and M. Ikhsan, "Peningkatan Kemampuan Berpikir Kritis Dan Disposisi Matematis Siswa Smp Dengan Menggunakan Pendekatan Problem Posing," Didakt. Mat., vol. 1, no. 2, pp. 43-53, 2014, doi: 10.24815/dm.v1i2.2076.

[15] Akhmad Riandy Agusta dan Noorhapizah, "Improving the Student 's Cooperation and Environmental Care Skill using Outdoor Learning Strategy Outbound Variation," $A d v$. Soc. Sci. Educ. Humanit. Res., vol. 274, pp. 1017, 2018.

[16] U. Sumarmo and I. Nishitani, "High Level Mathematical Thinking: Experiments With High School and Under Graduate Students Using Various Approaches and Strategies," 2010, [Online]. Available: https://gair.media.gunmau.ac.jp/dspace/bitstream/10087/5130/1/03_Nishi tani.pdf.

[17] G. Gunantara, M. Suarjana, and P. N. Riastini, "PENERAPAN MODEL PEMBELAJARAN PROBLEM BASED LEARNING UNTUK MENINGKATKAN KEMAMPUAN PEMECAHAN MASALAH MATEMATIKA SISWA KELAS V," J. Mimb. PGSD Univ. Pendidik. Ganesha, vol. 2, no. 1, 2014, doi: 10.15294/kreano.v10i2.19671.

[18] M. Hosnan, Pendekatan Saintifik dan Kontekstual Dalam Pembelajaran Abad 21: Kunci Sukses Implementasi Kurikulum 2013. Ghalia Indonesia, 2014.

[19] G. Lord and L. Lomicka, "Blended learning in teacher education: An investigation of classroom community across media," Contemp. Issues Technol. Teach. Educ., vol. 8, no. 2, pp. 158-174, 2008.

[20] J. Bersin, The Blended Learning Book:, Best Practices, Proven Methodologies, and Lessons Learned. USA: Pfeiffer Publishing, 2004.

[21] K. Thorne, Blended learning: How to integrate online and traditional learning. London: Kogan Page, 2003.

[22] A. Sutisna, "Pengembangan Model Pembelajaran Blended Learning pada Pendidikan Kesetaraan Program Paket $\mathrm{C}$ dalam Meningkatkan Kemandirian Belajar," J. Teknol. Pendidik., vol. 18, no. 3, pp. 156-168, 2016.

[23] R. Garner and E. Rouse, "Social presence connecting pre-service teachers as learners using a blended learning model," Student Success, vol. 7, no. 1, p. 25, 2016, doi: 10.5204/ssj.v7i1.299.

[24] R. B. Gall, Meredith D. Joyce P. Gall dan Walter, Educational Research: An Introduction (Seventh Edition). United States of America: Allyn and Bacon, 2003.

[25] Sugiyono, Metode Penelitian Kuantitatif Kualitatif dan R\&D. Bandung: Alfabeta, 2007.

[26] M. I. Thiagarajan, S., Semmel, D. S \& Semmel, Instructional Development for Training Teachers of Expectional Children. Minneapolis, Minnesota: Leardership Training 
Institure/Special Education, University of Minnesota, 1974.

[27] Hopkins, Desain Penelitian Tindakan Kelas (Model Ebbut). Yogyakarta: Pustaka Belajar, 1993.

[28] Iskandar, Metodologi Penelitian Kualitatif. Jakarta: Gaung Persada Press, 2009.

[29] N. Mahnun, "Media Pembelajaran (Kajian terhadap Langkah-langkah Pemilihan Media dan Implementasinya dalam Pembelajaran)," anNida', vol. 37, no. 1, pp. 27-35, 2012.

[30] D. E. Meltzer, "The relationship between mathematics preparation and conceptual learning gains in physics: A possible 'hidden variable' in diagnostic pretest scores," Am. J. Phys., vol. 70, no. 12, pp. 1259-1268, 2002, doi: 10.1119/1.1514215.

[31] H. Yunansah and Y. T. Herlambang, "Pendidikan berbasis ekopedagogik dalam menumbuhkan kesadaran ekologis dan mengembangkan karakter siswa sekolah dasar," vol. 9, no. 1, pp. 27-34, 2017.

[32] E. Sulastri, T. Haryadi, and E. Inayah, "Tingkat Kesadaran Ekologis Masyarakat Kampung Laut, Kabupaten Cilacap, Jawa Tengah," J. Kawistara, vol. 9, no. 1, p. 78, 2019, doi: 10.22146/kawistara.31484.

[33] D. Atmono, M. Rahmattullah, and S. Setiti, "Identification of Economic Learning Resources Based on Ecopedagogy Case Study on the Sago Industry in Pemakuan Village," 1st Int. Conf. Creat. Innov. Technol. Educ. (IC-CITE 2018), vol. 274, pp. 60-63, 2018.

[34] H. Baharun, "PENGEMBANGAN MEDIA PEMBELAJARAN PAI BERBASIS LINGKUNGAN MELALUI MODEL ASSURE," Cendekia, vol. 14, no. 2, 2016.

[35] N. Yulianti, "Pengaruh Model Inkuiri Terbimbing Berbasis Lingkungan Terhadap Kemampuan Pemahaman Konsep Dan Karakter," J. Cakrawala Pendas, vol. 2, no. 2, 2016, doi: 10.31949/jcp.v2i2.329.

[36] R. . Nugroho, "Paparan Pornografi dari Media Sosial dan Perilaku Berpacaran Pada Siswa SMK X, Kelurahan Cempaka Outih, Kecamatan Ciputat Timurr Kota Tanggerang Selatan Tahun 2015," Universitas Islam Negeri Syarif Hidayatullah, 2016.

[37] A. Y. Zukmadini, B. Karyadi, and W. Trisnawati, "Strategi Pembelajaran Biologi Berbasis Lingkungan Melalui Kombinasi Pembelajaran Indoor Dan Outdoor Sebagai Upaya Meningkatkan Keterampilan Proses Siswa Sma," Pros. Semin. Nas. Pendidik. Biol., pp. 148-155, 2018.

[38] G. D. S. Rahayu and R. Setiyadi, "Penerapan Model Project Citizen dalam Upaya
Meningkatkan Kecerdasan Ekologis," Mimb. Sekol. Dasar, vol. 5, no. 1, p. 31, 2018, doi: 10.17509/mimbar-sd.v5i1.9684.

[39] W. Burton, "Ecopedagogy, The Earth Charter, and Manitoba Curriculum, A Critical Content Analysis," 2019.

[40] S. E. Atmojo, "PENERAPAAN MODEL PEMBELAJARAN BERBASIS MASALAH DALAM Setyo Eko Atmojo IMPLEMENTATION OF PROBLEM-BASED LEARNING MODEL TO IMPROVE THE LEARNING ACHIEVEMENT IN ENVIRONMENT," J. Kependidikan, vol. 43, no. 2, pp. 134-143, 2013.

[41] L. Erviana, "Pemanfaatan Media Pembelajaran Berbasis Lingkungan Sebagai Sarana Praktikum IPA Untuk Meningkatkan Pemahaman Konsep Siswa Di SMP-It Ar Rahmah Pacitan," J. Din. Pendidik. Dasar, vol. 7, no. 2, pp. 71-77, 2015, [Online]. Available: http://jurnalnasional.ump.ac.id/index.php/Dinam ika/article/view/936.

[42] E. Okur-Berberoglu, "Ecological Dynamics Model and Ecopedagogy-Based Outdoor Experiential Education.," Int. Electron. J. Environ. Educ., vol. 7, no. 2, pp. 134-151, 2017.

[43] S. Butchart et al., "Improving critical thinking using web based argument mapping exercises with automated feedback," 270 Australas. J. Educ. Technol., vol. 25, no. 2, pp. 268-291, 2009.

[44] M. A. Alwadai, "Islamic Teachers ' Perceptions of Improving Critical Thinking Skills in Saudi Arabian Elementary Schools," J. Educ. Learn., vol. 3, no. 4, pp. 37-48, 2014, doi: 10.5539/jel.v3n4p37.

[45] S. Putu, K. Surata, and J. S. Lansing, "Engaging Student Teachers in Designing Ecopedagogy Learning Modules for Bali's Subak Culturan Landscape," NACTA J., pp. 139-143, 2015.

[46] R. M. Vieira and C. Tenreiro-vieira, "Fostering Scientific Literacy and Critical Thinking in Elementary Science Education," Int. J. Sci. Math. Educ., vol. 14, no. 4, pp. 659-680, 2016, doi: 10.1007/s10763-014-9605-2.

[47] Y. Fitria, F. N. Hasanah, and N. Gistituati, "Critical Thinking Skills of Prospective Elementary School Teachers in Integrated Science-Mathematics Lectures," J. Educ. Learn., vol. 12, no. 4, pp. 597-603, 2018, doi: 10.11591/edulearn.v12i4.9633.

[48] D. Djamas, V. Tinedi, and Yohandri, "Development of interactive multimedia learning materials for improving critical thinking skills," Int. J. Inf. Commun. Technol. Educ., vol. 14, no. 4, pp. 66-84, 2018, doi: 10.4018/IJICTE.2018100105 
[49] Y. Elfrida, Y. Siregar, R. Rachmadtullah, and N. Pohan, "The impacts of science, technology, engineering, and mathematics ( STEM ) on critical thinking in elementary school The impacts of science, technology, engineering, and mathematics ( STEM ) on critical thinking in elementary school," J. Phys. Conf. Ser., vol. 1175 , no. 1 , 2019, doi: 10.1088/17426596/1175/1/012156.

[50] N. Cavus and H. Uzunboylu, "Improving critical thinking skills in mobile learning," vol. 1, pp. 434-438, 2009, doi: 10.1016/j.sbspro.2009.01.078

[51] M. Caroselli, 50 Activities for Developing Critical Thinking Skills. London: HRD Press, 2009.

[52] I. Novikasari, "Pengembangan Kemampuan Berpikir Kritis Siswa melalui Pembelajaran Matematika Open-ended di Sekolah Dasar," J. Pemikir. Altern. Kependidikan, vol. 14, no. 2, pp. 1-13, 2009.

[53] A. N. Rahma, "PENGEMBANGAN PERANGKAT PEMBELAJARAN MODEL INKUIRI BERPENDEKATAN SETS MATERI KELARUTAN DAN HASILKALI KELARUTAN UNTUK MENUMBUHKAN KETERAMPILAN BERPIKIR KRITIS DAN EMPATI SISWA TERHADAP LINGKUNGAN," J. Educ. Res. Eval., vol. 1, no. 2, 2012.

[54] A. W. Raula Samsul Amarila, Noor Aini Habibah, "PENGEMBANGAN ALAT EVALUASI KEMAMPUAN BERPIKIR KRITIS SISWA PADA PEMBELAJARAN IPA TERPADU MODEL WEBBED TEMA LINGKUNGAN," USEJ, vol. 3, no. 2, pp. 563$569,2014$.

[55] S. Maričić and K. Špijunović, "Developing Critical Thinking in Elementary Mathematics Education through a Suitable Selection of Content and Overall Student Performance," Procedia - Soc. Behav. Sci., vol. 180, no. May, pp. 653-659, 2015, doi: 10.1016/j.sbspro.2015.02.174.

[56] R. R. M. Syutharidho, "Pengembangan Soal Berpikir Kritis untuk Siswa SMP Kelas VIII," Al-Jabar J. Pendidik. Mat., vol. 6, no. 2, pp. 219-227, 2015.

[57] K. H. S. Dwi Septiana Sari, "PENGEMBANGAN MULTIMEDIA BERBASIS MASALAH UNTUK MENINGKATKAN MOTIVASI BELAJAR DAN KEMAMPUAN BERPIKIR KRITIS SISWA," J. Inov. Pendidik. IPA, vol. 1, no. 2, pp. 153-166, 2015.

[58] M. Firdaus and I. Wilujeng, "Pengembangan LKPD inkuiri terbimbing untuk meningkatkan keterampilan berpikir kritis dan hasil belajar peserta didik," J. Inov. Pendidik. IPA, vol. 4, no. 1, pp. 26-40, 2018.

[59] H. S. Tanjung and S. A. Nababan, "MATEMATIKA BERORIENTASI MODEL PEMBELAJARAN BERBASIS MASALAH ( PBM ) UNTUK MENINGKATKAN KEMAMPUAN BERPIKIR KRITIS SISWA SMA SE-KUALA NAGAN RAYA ACEH," Genta Mulia, vol. IX, no. 2, pp. 56-70, 2018.

[60] B. Hartati, "Pengembangan alat peraga gaya gesek untuk meningkatkan keterampilan berpikir kritis siswa sma," J. Pendidik. Fis. Indones., vol. 6, pp. 128-132, 2010.

[61] dan T. P. Savitri Herdianawati, Herlina Fitrihidajati, "PENGEMBANGAN LEMBAR KEGIATAN SISWA ( LKS ) INKUIRI BERBASIS BERPIKIR KRITIS PADA," BioEdu2, vol. 2, no. 1, pp. 99-104, 2013.

[62] S. Hasan, F. M. Tumbel, and A. Duran Corebima, "Empowering Critical Thinking Skills in Indonesia Archipelago: Study on Elementary School Students in Ternate," J. Mod. Educ. Rev., vol. 3, no. 11, pp. 2155-7993, 2013.

[63] S. K. H. Shan Duta Sukma Pradana, Parno, "PENGEMBANGAN TES KEMAMPUAN BERPIKIR KRITIS PADA MATERI OPTIK GEOMETRI UNTUK MAHASISWA FISIKA," J. Penelit. dan Eval. Pendidik., vol. 21, no. 1, pp. 51-64, 2017.

[64] I. Selviani, "Pengembangan Modul Biologi Problem Based Learning Untuk Meningkatkan Kemampuan Berpikir Kritis Peserta Didik SMA," IJIS Edu Indones. J. Integr. Sci. Educ., vol. 1, no. 2, pp. 147-154, 2019.

[65] M. L. Yeh and H. H. Chen, "Effects of an educational program with interactive videodisc systems in improving critical thinking dispositions for RN-BSN students in Taiwan," Int. J. Nurs. Stud., vol. 42, no. 3, pp. 333-340, 2005, doi: 10.1016/j.ijnurstu.2004.06.008.

[66] P. A. Weissinger, Enhancing Thinking through Problem-based Learning Approaches. Singapore: Thomson Learning, 2004.

[67] P. Dwijananti and D. Yulianti, "PENGEMBANGAN KEMAMPUAN BERPIKIR KRITIS MAHASISWA MELALUI PEMBELAJARAN PROBLEM BASED INSTRUCTION PADA MATA KULIAH FISIKA LINGKUNGAN," J. Pendidik. Fis. Indones., vol. 6, pp. 108-114, 2010.

[68] A. Syahbana, "PENGEMBANGAN PERANGKAT PEMBELAJARAN BERBASIS KONTEKSTUAL UNTUK MENGUKUR KEMAMPUAN BERPIKIR KRITIS MATEMATIS SISWA SMP," Edumatica, vol. 02, no. 02, pp. 17-26, 2012. 
[69] M. Duran and İ. Dökme, "The effect of the inquiry-based learning approach on student' $\mathrm{s}$ critical -thinking," Eurasia J. Math. Sci. Technol. Educ., vol. 12, no. 12, pp. 2887-2908, 2016, doi: 10.12973/eurasia.2016.02311a.

[70] S. Wahyuni, "Pengembangan Bahan Ajar IPA Untuk Meningkatkan Kemampuan Berpikir Kritis Siswa SMP," in Prosiding Seminar Nasional Fisika dan Pendidikan Fisika (SNFPF), 2015, vol. 6, no. 1, pp. 300-305.

[71] S. Rijal and S. Bachtiar, "Hubungan antara Sikap, Kemandirian Belajar, dan Gaya Belajar dengan Hasil Belajar Kognitif Siswa," J. Bioedukatika, vol. 3, no. 2, p. 15, 2015, doi: 10.26555/bioedukatika.v3i2.4149.

[72] P. R. Nasution, E. Surya, and E. Syahputra, "Perbedaan Peningkatan Kemampuan Berpikir Kreatif Matematis dan Kemamdirian Belajar Siswa Pada Pembelajaran Berbasis Masalah dan Pembelajaran Konvensional di SMPN 4 Padangsidempuan," J. Parad., vol. 8, no. 3, pp. 38-57, 2015.

[73] A. Mulyana and U. Sumarmo, "Meningkatkan Kemampuan Penalaran Matematik dan Kemandirian Belajar Siswa SMP melalui Pembelajaran Berbasis Masalah," Didaktik, vol. 9, no. 1, pp. 40-51, 2015.

[74] A. I. Rahmah, Sudiyanto, and D. Octoria, "PENGEMBANGAN BAHAN AJAR INTERAKTIF UNTUK MENINGKATKAN KEMANDIRIAN BELAJAR SISWA PADA PEMBELAJARAN AKUNTASI," Tata Arta, vol. 2, no. 1, pp. 73-83, 2016.

[75] J. Chau and G. Cheng, "Towards understanding the potential of e-portfolios for independent learning: A qualitative study," Australas. J. Educ. Technol., vol. 26, no. 7, pp. 932-950, 2010.

[76] O. Ural, "Attidues of graduate students toward distance education, educational technologies and independent learning," Turkish Online J. Distance Educ., vol. 8, no. 4, pp. 34-43, 2007, doi: 10.17718/tojde.83072.

[77] R. Field, J. Duffy, and A. Huggins, "Teaching independent learning skills in the first year: A positive psychology strategy for promoting law student well-being," J. Learn. Des., vol. 8, no. 2, pp. 1-10, 2015.

[78] D. Wagener, "Promoting independent learning skills using video on digital language laboratories," Comput. Assist. Lang. Learn., vol. 19, no. 4-5, pp. 279-286, 2006, doi: 10.1080/09588220601043180.

[79] B. Meyer, N. Haywood, D. Sachdev, and and S. Faraday, "What is independent learning and what are the benefits for students?" Departement for Children, Schools and Families Research
Report, London, 2008.

[80] M. Ibrahim and M. Nur, Pengajaran Berdasarkan Masalah. Surabaya: Unesa University Press, 2000.

[81] U. Sumarmo, "Kemandirian Belajar: Apa, Mengapa, dan Bagaimana Dikembangkan Pada Peserta Didik," 2006.

[82] B. BsY, "Pengembangan Kemandirian Belajar Berbasis Nilai Untuk Meningkatkan Komunikasi Matematik," J. Pendidik. Mat. dan IPA, vol. 1, no. $1, \quad$ pp. 11-22, 2010, doi: 10.26418/jpmipa.v1i1.148.

[83] U. Sumarmo, W. Hidayat, R. Zukarnaen, M. Hamidah, and R. Sariningsih, "KEMAMPUAN DAN DISPOSISI BERPIKIR LOGIS, KRITIS, DAN KREATIF MATEMATIK (Eksperimen terhadap Siswa SMA Menggunakan Pembelajaran Berbasis Masalah dan Strategi Think-Talk-Write)," J. Pengajaran Mat. dan Ilmu Pengetah. Alam, vol. 17, no. 1, p. 17, 2012, doi: 10.18269/jpmipa.v17i1.228.

[84] I. W. Handayani, L., Nyoman, N., Dantes, N., \& Suastra, "Pengaruh Model Pembelajaran Mandiri terhadap Kemandirian Belajar dan Prestasi Belajar IPA Siswa Kelas VIII SMP N 3 Singaraja," Universitas Ganesha, 2013.

[85] R. Azka and R. H. Santoso, "Pengembangan Perangkat Pembelajaran Kalkulus Untuk Mencapai Ketuntasan dan Kemandirian Belajar Siswa," J. Ris. Pendidik. Mat., vol. 2, no. 1, pp. 78-91, 2015.

[86] M. Al Fatihah, "Hubungan Antara Kemandirian Kemandirian Belajar Belajar dengan dengan PAI Siswa Kelas III SDN Prestasi Belajar PAI Panularan Surakarta," At-Tarbawi J. Kaji. Kependidikan Islam, vol. 1, no. 1, pp. 1-12, 2016.

[87] E. Nurhayati, "Penerapan scaffolding untuk pencapaian kemandirian belajar siswa," $J$. Penelit. Pendidik. dan Pengajaran Mat., vol. 3, no. 1, pp. 21-26, 2017.

[88] M. E. Harrsion and and W. B. Whalley, "Combining student independent learning and peer advice to improve the quality of undergraduate dissertations," Planet, no. 16, 2006.

[89] M. Pokorny and H. Pokorny, "Widening participation in higher education: Student quantitative skills and independent learning as impediments to progression," Int. J. Math. Educ. Sci. Technol., vol. 36, no. 5, pp. 445-467, 2005, doi: 10.1080/00207390500062621.

[90] G. Kadarisma, "Meningkatkan Kemandirian Belajar Siswa Smp Dalam Matematika Dengan Menggunakan Pendekatan Saintifik," Symmetry Pas. J. Res. Math. Learn. Educ., vol. I, pp. 6166, 2016, doi: 10.23969/symmetry.v1i1.214. 
[91] I. Lestari, "Pengembangan Layanan Informasi Teknik Symbolic Model Dalam Membantu Mengembangkan Kemandirian Belajaranak Usia Sekolah Dasar," J. Konseling Gusjigang, vol. 1, no. 1, 2015, doi: 10.24176/jkg.v1i1.261.

[92] B. A.M and E. Rohaeti, "MENGEMBANGKAN KEMAMPUAN BERPIKIR KREATIF DAN KEMANDIRIAN BELAJAR SISWA SMA MELALUI PEMBELAJARAN BERBASIS MASALAH," J. Pengajaran MIPA, vol. 19, no. 2, pp. 166-172, 2014.

[93] K. Swandhana, M. Churiyah, and L. Juariyah, "Meningkatkan Kemandirian Belajar dan Hasil Belajar Siswa melalui Pengembangan Modul Administrasi Kepegawaian Berbasis Strategi Pembelajaran Inkuiri Terbimbing," J. Pendidik. Bisnis dan Manaj., vol. 2, no. 3, pp. 161-169, 2016.

[94] I. D. Pratiwi and H. Laksmiwati, "Kepercayaan Diri dan Kemandirian Belajar Pada Siswa SMA Negeri ' $X$ ' Iffa Dian Pratiwi, dan Hermien Laksmiwati Program Studi Psikologi Universitas Negeri Surabaya," J. Psikol. Teor. Terap., vol. 7, no. 1, pp. 43-49, 2016.

[95] N. Fahradina, B. I. Ansari, and Salman, "Peningkatan Kemampuan Komunikasi Matematis dan Kemandirian Belajar Siswa SMP dengan Menggunakan Model Investigasi Kelompok," J. Didakt. Mat., vol. 1, no. 1, pp. 303-323, 2014.

[96] E. Sutarno and Mukhidin, "Pengembangan Model Pembelajaran Berbasis Multimedia Interaktif Pengukuran Untuk Meningkatkan Hasil Dan Kemandirian Belajar Siswa SMP Di Kota Bandung," J. Pendidik. Teknol. dan Kejuru., vol. 21, no. 3, pp. 1-1, 2015, doi: 10.21831/jptk.v21i3.3258.

[97] W. D. Pramana and N. R. Dewi, "Pengembangan E-Book Ipa Terpadu Tema Suhu Dan Pengukuran Untuk Menumbuhkan Kemandirian Belajar Siswa," USEJ - Unnes Sci. Educ. J., vol. 3, no. 3, 2014, doi: 10.15294/usej.v3i3.4267.

[98] Hamid Saremi \& Sosan Bahdari, "The Relationship between Critical Thinking with Emotional Intelligence and Creativity among Elementary School Principals in Bojnord City, Iran," Int. J. if Life Sci., vol. 9, no. 6, pp. 33-40, 2015.

[99] N. F. Amalia and E. Susilaningsih, "PENGEMBANGAN INSTRUMEN PENILAIAN KETERAMPILAN BERPIKIR KRITIS SISWA SMA PADA MATERI ASAM BASA," J. Inov. Pendidik. Kim., vol. 8, no. 2, pp. 1380-1389, 2014.

[100] M. Y. Ridho and Wasis, "Pengembangan Media Pembelajara Berbasis Prezi untuk meningkatkan keterampilan Berpikir Kritis Pada Materi Kalor," Inov. Pendidik. Fis., vol. 3, no. 2, pp. 137-142, 2014.

[101] G. A. M. I M. Suarsana, "PENGEMBANGAN E-MODUL BERORIENTASI PEMECAHAN MASALAH UNTUK MENINGKATKAN KETERAMPILAN BERPIKIR KRITIS MAHASISWA," J. Pendidik. Indones., vol. 2, no. 2, pp. 264-275, 2013.

[102] A. Facione, P., Measure reasons critical thinking: what it is and why it counts (rev. ed.). Millbrae, CA: Insight Assessment, 2011.

[103] J. C. Ricketts and R. D. Rudd, "Critical thinking skills of selected youth leaders: the efficacy of critical thinking dispositions, leadership, and academic performance," J. Agric. Educ., vol. 46, no. $1,2005$.

[104] J. R. Savery, "Overview of Problem-based Learning: Definitions and Distinctions," Interdiscip. J. Probl. Learn. Vol., vol. 1, no. 1, 2006.

[105] M. F. C. P. Ningrum, Slameto, and E. Widyanti, "Upaya Meningkatkan Keterampilan Kerjasama Siswa pada Bidang Studi IPA Melalui Penerapan Model Group Investigation bagi Siswa Kelas 5 SDN Kumpulrejo 2," Wahana Kreat. Pendidik, vol. I, no. 3, pp. 7-13, 2018.

[106] A. Azis, D. Yulianti, L. Handayani, and P. B. Mengajar, "Penerapan Model Pembelajaran Kooperatif Dengan Memanfaatkan Alat Peraga Sains Fisika (Materi Tata Surya) Untuk Meningkatkan Hasil Belajar Dan Kerjasama Siswa," J. Pendidik. Fis. Indones., vol. 4, no. 2 , pp. 94-99, 2006, doi: 10.15294/jpfi.v4i2.162.

[107] T. NA, "Meningkatkan Keterampilan Kerjasama Siswa Pada Tema Pengalamanku Menggunakan Model Pembelajaran Number Head Together (NHT)," J. Ilm. Wahana Pendidik., vol. 6, no. 2 , 2020, doi: 10.5281/zenodo.3740939.

[108] E. Nurnawati, D. Yulianti, and H. Susanto, "PENINGKATAN KERJASAMA SISWA SMP MELALUI PENERAPAN PEMBELAJARAN KOOPERATIF PENDEKATAN THINK PAIR SHARE," UPEJ, vol. 1, no. 2257, 2012.

[109] S. Fauziyah and A. Hendriani, "PENINGKATAN KETERAMPILAN KERJASAMA MELALUI MODEL PEMBELAJARAN KOOPERATIF TEAMS GAMES TOURNAMENT KELAS III SEKOLAH DASAR," J. Pendidik. Guru Sekol. Dasar, vol. 4, no. 2, pp. 196-210, 2019.

[110] R. Amini and A. Muandar, "Pengaruh Model Pembelajaran Pendidikan Lingkungan berbasis Outdoor terhadap Penguasaan Konsep Pendidikan Lingkungan Bagi Calon Guru Sekolah Dasar," J. Penelit. Pendidik., vol. 11, no. 1, pp. 14-21, 2010. 
[111] E. OKUR-BERBEROGLU, "The Effect of Ecopodagogy-Based Environmental Education on Environmental Attitude of In-service Teachers," Int. Electron. J. Environ. Educ., vol. 5, no. 2, pp. 86-110, 2015, doi: 10.18497/iejeegreen.09988.

[112] I. D. P. Subamia, I. G. A. N. S. Wahyuni, and N. N. Widiasih, "Pengembangan Perangkat Penunjang Praktikum IPA SMP Berorientasi Lingkungan," J. Pendidik. Dan Pengajaran, vol. 47, no. 1, pp. 29-39, 2014.

[113] T. Setiyoningsih, "Pengelolaan Pembelajaran Ipa Berbasis Lingkungan di SMPN 1 GabusGrobogan," J. Manaj. Pendidik., vol. 12, no. 1, pp. 1-9, 2017.

[114] D. Enersy, B. Karyadi, and E. W. Winarni, "KURA-KURA UNIVERSITAS BENGKULU DAN PENGEMBANGAN," PENDIPA J. Sci. Educ., vol. 1, no. 2, pp. 55-61, 2017.

[115] P. N. Adi, "The influence of the implementation of Peer Teaching learning strategy in the course of occupational therapy on learning outcomes of students with special needs in the extraordinary Education Department of IKIP PGRI Jember," J. Incl. Educ., vol. 2, no. 2, pp. 117-123, 2019.

[116] D. Desriana, A. Amsal, and D. Husita, "Perbandingan Hasil Belajar Siswa Menggunakan Media Pembelajaran Berbasis Lingkungan Dengan Media Internet Dalam Pembelajaran Asam Basa di MAN Indrapuri," J. IPA dan Pembelajaran IPA, vol. 02, no. 01, pp. 51-55, 2018.

[117] G. J. Hwang, C. M. Hung, and N. S. Chen, "Improving learning achievements, motivations and problem-solving skills through a peer assessment-based game development approach," Educ. Technol. Res. Dev., vol. 62, no. 2, pp. 129-145, 2014, doi: 10.1007/s11423-013-93207.

[118] Mulyadi, Marzuki, and A. Usman, "Implementasi pembelajaran tematik terpadu berbasis lingkungan untuk perolehan kemampuan berpikir tingkat tinggi di sd," $J$. Inov., vol. 02, pp. 1-15, 2017.

[119] C. Cornoldi, B. Carretti, S. Drusi, and C. Tencati, "Improving problem solving in primary school students: The effect of a training programme focusing on metacognition and working memory Improving problem solving in primary school students : The effect of a training programme focusing on metacognition and," $\mathrm{Br}$. J. Educ. Psychol., vol. 85, 2015, doi: 10.1111/bjep. 12083.

[120] M. Fitriati, R. Sahputra, and I. Lestari, "Pengaruh Pembelajaran Berbasis Lingkungan Terhadap Sikap Peduli Lingkungan Pada Materi Pencemaran Lingkungan," J. Pendidik. dan
Pembelajaran Khatulistiwa, vol. 8, no. 1, pp. 18, 2019, [Online]. Available: http://jurnal.untan.ac.id/index.php/jpdpb/article/ view/30614.

[121] S. Edy, J. Sabandar, Y. S. Kusumah, and Darhim, "Mathematical Problem Solving by Schoenfeld.pdf," IndoMS. J.M.E, vol. 4, no. 1, pp. 113-126, 2013.

[122] M. P. P. I. W. Neka, I. K., Marhaeni, M. P. A. N., \& Suastra, "Pengaruh model pembelajaran inkuiri terbimbing berbasis lingkungan terhadap keterampilan berpikir kreatif dan penguasaan konsep IPA Kelas V SD Gugus VIII Kecamatan Abang," Universitas Ganesha, 2015.

[123] M. J. \& Sihkabuden, "Implementation of the students ' disability Model with Disability Study Center (PSLD) of Universitas Brawijaya Malang," Orthop. J., vol. 3, no. 1, pp. 45-50, 2017.

[124] J. L. Whipple, M. J. Lambert, D. A. Vermeersch, D. W. Smart, S. L. Nielsen, and E. J. Hawkins, "Improving the effects of psychotherapy: The use of early identification of treatment failure and problem-solving strategies in routine practice," J. Couns. Psychol., vol. 50, no. 1, pp. 59-68, 2003, doi: 10.1037/0022-0167.50.1.59.

[125] M. Zunanda and K. Sinulingga, "Pengaruh Model Pembelajaran Berbasis Masalah Dan Kemampuan Berpikir Kritis Terhadap Keterampilan Pemecahan Masalah Fisika Siswa Smk," J. Pendidik. Fis., vol. 4, no. 1, p. 63, 2015, doi: 10.22611/jpf.v4i1.2570.

[126] T. S. Sumartini, "Peningkatan Kemampuan Pemecahan Masalah Matematis Siswa melalui Pembelajaran Berbasis Masalah," Mosharafa J. Pendidik. Mat., vol. 5, no. 2, pp. 148-158, 2016, doi: 10.31980/mosharafa.v5i2.270.

[127] A. D. Sari and S. H. Noer, "Kemampuan Pemecahan Masalah Matematis Dengan Model Creative Problem Solving (CPS) Dalam Pembelajaran Matematika," Pros. Semin. Nas. Mat. dan Pendidik. Mat. 2017, pp. 245-252, 2017.

[128] E. Surya, F. A. Putri, and Mukhtar, "Improving mathematical problem-solving ability and selfconfidence of high school students through contextual learning model," J. Math. Educ., vol. 8, no. 1, pp. 85-94, 2017, doi: 10.22342/jme.8.1.3324.85-94.

[129] I. A. T. Rahayu and G. A. Y. P. Adistana, "Mengembangkan Keterampilan Memecahkan Masalah melalui Pembelajaran Berdasar Masalah," J. Pendidik. (Teori dan Prakt., vol. 3, no. 2, p. 86, 2018, doi: 10.26740/jp.v3n2.p8691.

[130] E. E. Napitupulu, "Mengembangkan Strategi dan 
Kemampuan Siswa Memecahkan Masalah Matematik," Pythagoras J. Pendidik. Mat., vol. 4, no. 2, pp. 26-36, 2008, doi: 10.21831/pg.v4i2.557.

[131] J. Sulianto, "Keefektifan Model Pembelajaran Kontekstual dengan pendekatan open ended dalam aspek penalaran dan pemecahan masalah pada materi segitiga di kelas VII.," Malih Peddas (Majalah Ilm. Pendidik. Dasar), vol. 1, no. 1, 2011, doi: 10.26877/malihpeddas.v1i1.64.

[132] I. W. Redhana, "Model Pembelajaran Berbasis Masalah untuk Peningkatan Keterampilan Pemecahan Masalah dan Berpikir Kritis," J. Pendidik. dan Pengajaran, vol. 46, no. 1, pp. 76-86, 2013.

[133] M. Surur, T. Triyono, and D. M. Handarini, "Keefektifan Problem Solving Strategy (PSS) untuk meningkatkan keterampilan memecahkan masalah pada siswa SMP," J. Pendidik. Teor. Penelitian, dan Pengemb., vol. 1, no. 11, pp. 2211-2219, 2016.

[134] S. K. Fajarwati, H. Susilo, and S. E. Indriwati, "Pengaruh Project Based Learning Berbantuan Multimedia terhadap Keterampilan Memecahkan Masalah dan Hasil Belajar Psikomotor Siswa Kelas XI SMA," J. Pendidik. Teor. Penelitian, dan Pengemb., vol. 2, no. 3, pp. 315-321, 2017.

[135] S. Rustam E, D. R. Sidabutar, and S. Edy, "Improving Learning Activity and Students" Problem Solving Skill through Problem Based Learning (PBL) in Junior High School," Int. J. Sci. Basic Appl. Res., vol. 33, no. 2, pp. 321331, 2017, [Online]. Available: http://gssrr.org/index.php?journal=JournalOfBas icAndApplied.

[136] M. G. Jayadiningrat and E. K. Ati, "Peningkatan Keterampilan Memecahkan Masalah Melalui Model Pembelajaran Problem Based Learning (Pbl) Pada Mata Pelajaran Kimia," J. Pendidik. Kim. Indones., vol. 2, no. 1, p. 1, 2018, doi: 10.23887/jpk.v2i1.14133.

[137] C. M. Hung, G. J. Hwang, and I. Huang, "A project-based digital storytelling approach for improving students' learning motivation, problem-solving competence and learning achievement," Educ. Technol. Soc., vol. 15, no. 4, pp. 368-379, 2012.

[138] Wijayanto, S. E. Nugroho, and D. Usrotin, "PENERAPAN PEMBELAJARAN MELALUI KEGIATAN LABORATORIUM INKUIRI TERBIMBING UNTUK MENINGKATKAN KEMAMPUAN PEMECAHAN MASALAH, BERKOMUNIKASI, DAN BEKERJASAMA," Unnes Phys. Educ. J., vol. 2, no. 2, pp. 49-54, 2013.

[139] F. Rosma, "Peningkatan keterampilan
Memecahkan Masalah Materi Pencemaran Lingkungan Melalui Project Based Learning Pada Siswa Man Model Banda Aceh," in Prosiding Seminar Nasional Biotik, 2015, pp. 502-505.

[140] M. Supiandi and H. Julung, "Pengaruh Model Problem Based Learning (PBL) terhadap Kemampuan Memecahkan Masalah dan Hasil Belajar Kognitif Siswa Biologi SMA," JPS (Jurnal Pendidik. Sains), vol. 4, no. 2, pp. 6064, 2016.

[141] H. Cahyani and R. W. Setyawati, "Pentingnya Peningkatan Kemampuan Pemecahan Masalah melalui PBL untuk Mempersiapkan Generasi Unggul Menghadapi MEA,” pp. 151-160, 2016.

[142] C. Y. Eviyanti, E. Surya, E. Syahputra, and M. Simbolon, "Improving the Students' Mathematical Problem Solving Ability by Applying Problem Based Learning Model in VII Grade at SMPN 1 Banda Aceh Indonesia," Int. J. Nov. Res. Educ. Learn., vol. 4, no. 2, pp. 138144, 2017, [Online]. Available: https://www.researchgate.net/publication/31852 9138.

[143] S. D. Craig, M. T. H. Chi, and K. Vanlehn, "Improving Classroom Learning by Collaboratively Observing Human Tutoring Improving Classroom Learning by Collaboratively Observing Human Tutoring Videos While Problem Solving," J. Educ. Psyhology, vol. 101, 2009, doi: 10.1037/a0016601.

[144] G. J. Hwang, C. Y. Chen, P. S. Tsai, and C. C. Tsai, "An expert system for improving webbased problem-solving ability of students," Expert Syst. Appl., vol. 38, no. 7, pp. 86648672, 2011, doi: 10.1016/j.eswa.2011.01.072.

[145] D. M. Grace and J. W. Gilsdorf, "Classroom strategies for improving students' oral communication skills," J. Account. Educ., vol. 22, no. 2, pp. 165-172, 2004, doi: 10.1016/j.jaccedu.2004.06.001.

[146] L. Hite, K. Mcdonald, L. Bierema, J. Gedro, and D. Kravitz, "The importance of diversity in the HRD curriculum," Organ. Leadersh. Superv. Fac. Present., Jan. 2009.

[147] L. E. Margulieux, W. M. McCracken, and R. Catrambone, "A taxonomy to define courses that mix face-to-face and online learning," Educ. Res. Rev., vol. 19, pp. 104-118, 2016, doi: 10.1016/j.edurev.2016.07.001.

[148] P. Kasapoğlu-Akyol, "Using educational technology tools to improve language and communication skills of ESL students," NovitasRoyal, vol. 4, no. 2, pp. 225-241, 2010, [Online]. Available: http://www.emich.edu/ois/visaissues/Stats_int'le 
xchange_MI.htm.

[149] H. Kashefi, Z. Ismail, and Y. M. Yusof, "The Impact of Blended Learning on Communication Skills and Teamwork of Engineering Students in Multivariable Calculus," Procedia - Soc. Behav. Sci., vol. 56, no. Ictlhe, pp. 341-347, 2012, doi: 10.1016/j.sbspro.2012.09.662.

[150] E. Yanti, S. Haryani, and K. I. Supardi, "Pengembangan Bahan Ajar Koloid Bermuatan Karakter Berbasis Discovery-Inquiry Untuk Meningkatkan Keterampilan Berkomunikasi Siswa SMA," J. Innov. Sci. Educ., vol. 4, no. 1, pp. 1-9, 2015.

[151] A. F. Nizatama, R. B. Rudibyani, and E. Sofya, "Efektivitas Media E-Book untuk Meningkatkan Keterampilan Komunikasi dan Penguasaan Konsep Siswa," J. Pendidik. dan Pembelalajaran Kim., vol. 8, no. 3, 2019.

[152] A. Fadli and Irwanto, "The effect of local wisdom-based ELSII learning model on the problem solving and communication skills of pre-service islamic teachers," Int. J. Instr., vol. 13, no. 1, pp. 731-746, 2020, doi: 10.29333/iji.2020.13147a.

[153] I. Alhaddad, Y. S. Kusumah, J. Sabandar, and J. A. Dahlan, "ENHANCING STUDENTS , COMMUNICATION SKILLS THROUGH TREFFINGER TEACHING MODEL," IndoMS$J M E$, vol. 6, no. 1, pp. 31-39, 2015.

[154] R. S. Dewi, U. Kultsum, and A. Armadi, "Using Communicative Games in Improving Students , Speaking Skills," English Lang. Teach., vol. 10, no. 1, pp. 63-71, 2017, doi: 10.5539/elt.v10n1p63.

[155] S. S. Dewi, D. A. Uswatun, and A. Sutisnawati, "Penerapan Model Inside Outside Circle Untuk Meningkatkan Keterampilan Komunikasi Siswa Dalam Pembelajaran IPA di Kelas Tinggi," J. Utile, vol. VI, no. 1, 2020.

[156] Q. Alam and A. B. Uddin, "IMPROVING ENGLISH ORAL COMMUNICATION SKILLS OF PAKISTANI PUBLIC SCHOOL'S STUDENTS," Int. J. English Lang. Teach., vol. 1, no. 2, pp. 17-36, 2013.

[157] Y. Chung, J. Yoo, W. Kim, H. Lee, and D. L. Zeidler, 'Enhancing students' communication skills in the science classroom through socioscientific issues," Int. J. Sci. Math. Educ., vol. 14, no. 1, pp. 1-27, 2016, doi: 10.1007/s10763-014-9557-6.

[158] A. . Oktaviani and N. S.E, "Penerapan Model Creative Problem Solving Pada Pembelajaran Kalor Untuk Meningkatkan Pemahaman Konsep Dan Keterampilan Komunikasi," UPEJ Unnes Phys. Educ. J., vol. 4, no. 1, 2015, doi: 10.15294/upej.v4i1.4733.

[159] N. U. Husnah and E. Surya, "The Effectiveness of Think Talk Write Learning Model in Improving Students' Mathematical Communication Skills at MTs Al Jami'yatul Washliyah Tembung," Int. J. Sci. Basic Appl. Res., vol. 34, no. 2, pp. 1-12, 2017.

[160] D. K. Inten, R. Hermawan, and Kurniasih, "Penerapan Pembelajaran Kooperatif Tipe Numbered Head Together Untuk Meningkatkan Keterampilan Kerjasama Siswa Kelas III Sekolah Dasar," J. Pendidik. Guru Sekol. Dasar, vol. 4, no. 3, pp. 444-451, 2019, doi: 10.17509/jpgsd.v4i3.23472.

[161] D. A. Kisworo, W. Wasitohadi, and T. S. Rahayu, "Perbedaan Efektivitas Group Investigation Dengan Problem Based Learning Terhadap Kerjasama Siswa Mata Pelajaran Ipa Siswa Kelas 5 Sd Gugus Joko Tingkir," $J$. Basicedu, vol. 3, no. 1, pp. 66-75, 2019, doi: 10.31004/basicedu.v3i1.77.

[162] D. Fitriani, T. Jalmo, and B. Yolida, "Pengaruh Problem Based Learning Terhadap Keterampilan Kolaborasi dan Berpikir Tingkat Tinggi," $J$. Bioterdidik, vol. 7, no. 2, pp. 35-45, 2019, [Online]. Available: http://jurnal.fkip.unila.ac.i255d/index.php/JBT/a rticle/view/17.

[163] M. Desfandi, E. Maryani, and Disman, "Implementasi kebijakan sekolah berwawasan lingkungan sebagai upaya mengembangkan literasi ekologis peserta didik," Sosio Didakt. Soc. Sci. Educ. J., vol. 4, no. 2, pp. 30-38, 2017.

[164] S. H. N. Hafida et al., "Green Literature untuk Menumbuhkembangkan Kesadaran Ekologis di SD Muhammadiyah Program Khusus Bayat, Klaten," Bul. KKN Pendidik., vol. 2, no. 1, pp. 37-43, 2020, doi: 10.23917/bkkndik.v2i1.10795.

[165] M. N. Siddiq, B. Supriatno, and S. Saefudin, "Pengaruh penerapan problem based learning terhadap literasi lingkungan siswa SMP pada materi pencemaran lingkungan," Assim. Indones. J. Biol. Educ., vol. 3, no. 1, pp. 18-24, 2020, doi: 10.17509/aijbe.v3i1.23369.

[166] G. Han, O. P. McCubbins, and T. H. Paulsen, "Using Social Network Analysis to Measure Student Collaboration in an Undergraduate Capstone Course," NACTA J., vol. 60, no. 2, p. 176, 2016.

[167] D. Diziol, E. Walker, N. Rummel, and K. Koedinger, "Using Intelligent Tutor Technology to Implement Adaptive Support for Student Collaboration," Educ. Psychol. Rev., vol. 22, pp. 89-102, Mar. 2010, doi: 10.1007/s10648-0099116-9.

[168] C. Dickerson, J. Jarvis, and L. Stockwell, "Staff-student collaboration: student learning from working together to enhance educational practice in higher education," Teach. High. 
Educ., vol. 21, pp. 1-17, Jan. 2016, doi: 10.1080/13562517.2015.1136279.

[169] C. Koppe, M. Van Eekelen, and S. Hoppenbrouwers, "Improving Student Group Work with Collaboration Patterns: A Case Study," Proc. - Int. Conf. Softw. Eng., vol. 2, pp. 303-306, 2015, doi: 10.1109/ICSE.2015.160.

[170] K. Haycock, "Collaboration: Critical Success Factors for Student Learning," Sch. Libr. Worldw., vol. 13, no. 1, pp. 25-35, 2007, [Online]. Available: http://ezproxy.csu.edu.au/login?url=http://search .ebscohost.com/login.aspx?direct $=$ true $\& d b=l i h \&$ $\mathrm{AN}=25545933 \&$ site $=$ ehost-live.

[171] L. R. Hanlan, R. A. Ziino, and A. H. Hoffman, "Assessing student information literacy skills and the effectiveness of an evolving facultylibrarian collaboration in a first year design course," Proc. - Front. Educ. Conf. FIE, pp. 1444-1446, 2013, doi: 10.1109/FIE.2013.6685070.

[172] S. Kathleen, "Student Collaboration and School Educational Technology: Technology Integration Practices in the Classroom," $i$ manager's J. Sch. Educ. Technol., vol. 11, no. 4, p. 53, 2016, doi: 10.26634/jsch.11.4.6012.

[173] H. Le, J. Janssen, and T. Wubbels, "Collaborative learning practices: teacher and student perceived obstacles to effective student collaboration," Cambridge J. Educ., vol. 48, no. 1, pp. 103-122, 2018, doi: 10.1080/0305764X.2016.1259389.

[174] K. Ofstedal and K. Dahlberg, "Collaboration in student teaching: Introducing the collaboration self-assessment tool," J. Early Child. Teach. Educ., vol. 30, no. 1, pp. 37-48, 2009, doi: 10.1080/10901020802668043.

[175] N. M. Moolenaar, P. J. C. Sleegers, and A. J. Daly, "Teaming up: Linking collaboration networks, collective efficacy, and student achievement," Teach. Teach. Educ., vol. 28, no.
2, pp. 251-262, 2012, doi: 10.1016/j.tate.2011.10.001.

[176] M. Smith and A. Dailey, "Improving and Assessing Information Literacy Skills through Faculty-Librarian Collaboration," Coll. Undergrad. Libr., vol. 20, pp. 314-326, Jul. 2013, doi: 10.1080/10691316.2013.829370.

[177] H. Trisdiono, S. Siswandari, N. Suryani, and S. Joyoatmojo, "Multidisciplinary integrated project-based learning to improve critical thinking skills and collaboration," Int. J. Learn. Teach. Educ. Res., vol. 18, no. 1, pp. 16-30, 2019, doi: 10.26803/ijlter.18.1.2.

[178] M. Yusuf, I. Tarjiah, and O. Satibi, "Penerapan Metode Simulasi Untuk Meningkatkan Keterampilan Sosial Siswa Dalam Pembelajaran Ips," J. Tunas Bangsa, vol. 5, no. 2, pp. 124132, 2018.

[179] H. Zulfikar, N. Supriatna, and I. Nurbaeti, "Theoretical Aspects Of Ecological Intelligence Development Of Students In Elementary Schools," 2nd Int. Conf. Elem. Educ., vol. 2, no. 1, pp. 803-813, 2013.

[180] W. Fitriana and D. Mulyono, "Implication Of Internship III Program on Ecological Awareness of Cihampelas Village Community," J. Ilm. P2M STKIP Siliwangi, vol. 6, no. 2, pp. 203 208, 2019.

[181] Y. F. Narut and M. Nardi, "Analisis Sikap Peduli Lingkungan Pada Siswa Kelas VI Sekolah Dasar di Kota Ruteng," Sch. J. Pendidik. dan Kebud., vol. 9, no. 3, pp. 259266, 2019, doi: 10.24246/j.js.2019.v9.i3.p259266.

[182] H. Yunansah, K. Kuswanto, and F. Abdillah, "Ekopedagogik: Analisis Pola Pendidikan Di Sekolah Alam Bandung," EduHumaniora $\mid J$. Pendidik. Dasar Kampus Cibiru, vol. 12, no. 2, pp. 115-124, 2020, doi: 10.17509/eh.v12i2.20597. 